\title{
Working
}

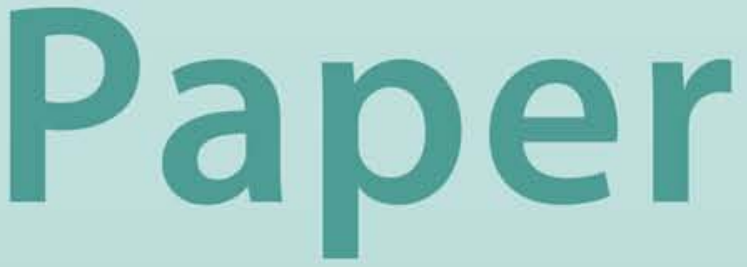


Reforming Government Subsidies in the

New Member States of the European Union

Carlos Mulas-Granados, Taline Koranchelian, and Alex Segura-Ubiergo 


\title{
IMF Working Paper
}

\author{
Fiscal Affairs Department
}

\section{Reforming Government Subsidies in the New Member States of the European Union}

\author{
Prepared by Carlos Mulas-Granados, Taline Koranchelian, and Alex Segura-Ubiergo*
}

Authorized for distribution by Rolando Ossowski and Gerd Schwartz

July 2008

\begin{abstract}
This Working Paper should not be reported as representing the views of the IMF.

The views expressed in this Working Paper are those of the author(s) and do not necessarily represent those of the IMF or IMF policy. Working Papers describe research in progress by the author(s) and are published to elicit comments and to further debate.
\end{abstract}

Subsidy reform has been a key component of the pre-accession reform agenda of the 10 new member states that joined the EU in 2004 (EU-10). During the pre-accession period, these countries had to undertake a number of important structural reforms in their economies. One of the most critical reforms was to reduce, and in some cases, eliminate their subsidy programs. This paper analyzes how key subsidy reforms (in state aid to enterprises, agriculture, energy, and transportation) were carried out in the EU-10 during 1995-2005, and explains observed variations across types of subsidies and across countries. Based on an extensive qualitative analysis, the paper draws lessons for future successful reforms of government subsidies.

32B

JEL Classification Numbers: H2; H21; H23; H4.

Keywords: European Union, new member states, subsidy reform, state aid to enterprises, agricultural subsidies, energy subsidies, and transportation subsidies

Authors’ E-Mail Addresses: cmulasgranados@ccee.ucm.es; tkoranchelian@imf.org; aseguraubiergo@imf.org

\footnotetext{
*Carlos Mulas-Granados is a tenured professor at the Applied Economics Department, Complutense University, Madrid, and was a visiting scholar in the IMF's Fiscal Affairs Department (FAD) in the summer of 2006.

Taline Koranchelian is a senior economist in FAD. Alex Segura-Ubiergo was an economist in FAD when the work on this paper started, and is now with the IMF's African Department. The usual disclaimer applies.
} 


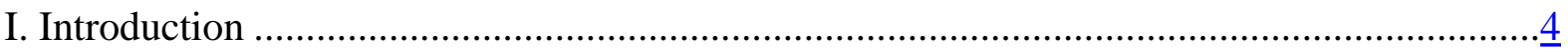

II. Overview of Subsidy Reform in the New Member States ............................................... $\underline{5}$

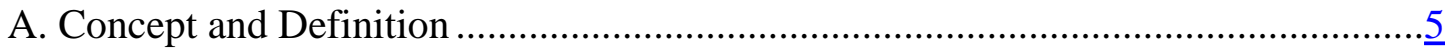

B. From Transition to EU Accession ....................................................................... $\frac{6}{7}$

C. Size and Composition of Subsidies .....................................................................

III. Analytical Framework Explaining Differences in Subsidy Reform Experiences ............... $\underline{8}$

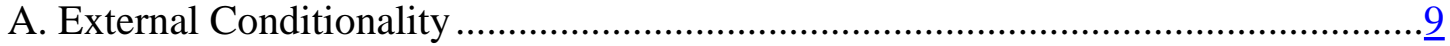

B. Domestic Constraints .........................................................................

C. Subsidy Reform in the New Member States: Underlying Factors .........................

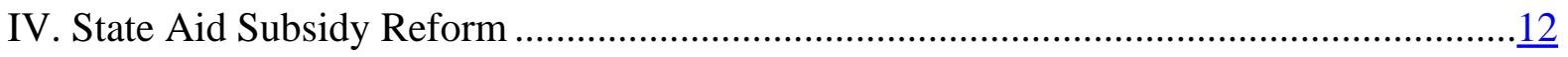

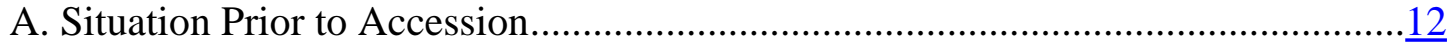

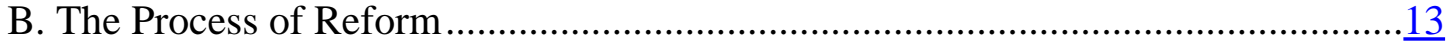

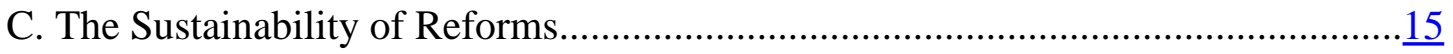

V. Agricultural Subsidy Reform ........................................................................ 15

A. Situation Prior to Accession.................................................................... $\frac{15}{16}$

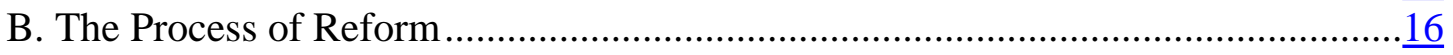

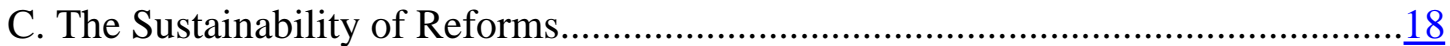

VI. Energy Subsidy Reform........................................................................................ 19

A. Situation Prior to Accession.................................................................... $\frac{19}{20}$

B. The Process of Reform ............................................................................. $\frac{20}{22}$

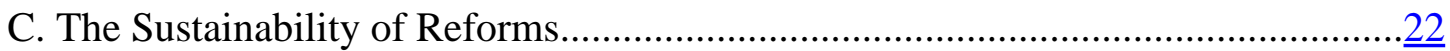

VII. Transport Subsidy Reform ................................................................................ 24

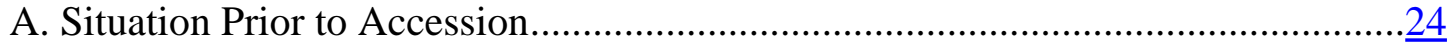

B. The Process of Reform ............................................................................ $\frac{25}{27}$

C. The Sustainability of Reforms....................................................................

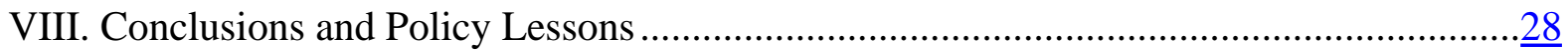

Tables

1. Size of Subsidies

2. Reductions in Subsidies by Type ...............................................................................

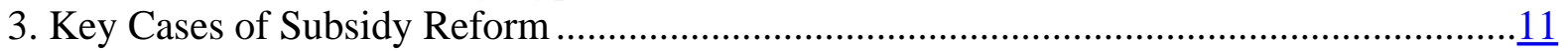

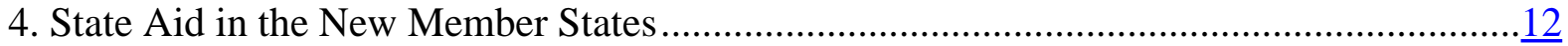

5. Instruments to Finance State Aid for Manufacturing and Services ................................13

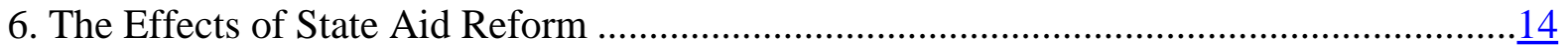

7. Agricultural Subsidies in the New Member States ........................................................ $\frac{17}{17}$

8. Share of Different Farm Types in Total Agricultural Land .............................................17

9. Energy Subsidies in the New Member States ...............................................................20

10. New Instruments for Promoting Renewable Energies in the New Member States ...........21

11. Power Sector Regulatory Bodies in the New Member States........................................24 
12. Transport Subsidies in the New Member States

13. State Aid for Horizontal Objectives and Particular Sectors..................................................

Figures

1. External Conditionality and Variation of Reform Across Types of Subsidy

2. State Aid Being Phased Out During Accession ..................................................................13

3. Distribution of new EU's Agricultural Subsidies during Accession .....................................16

4. Agricultural Income in the Old and New Member States..............................................

5. The Impact of Subsidy Reform on Household Expenditures ........................................21

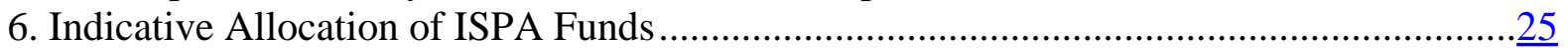

Appendixes

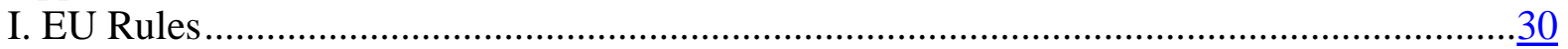

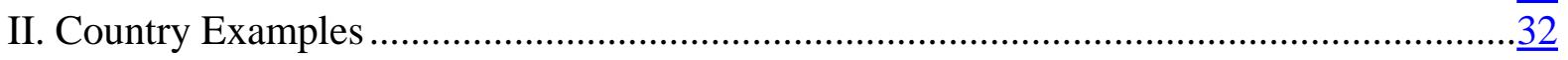

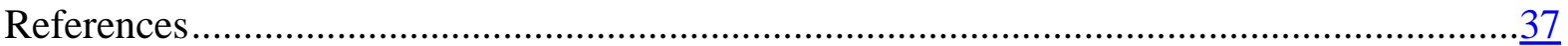




\section{INTRODUCTION}

Subsidy reform has been a key component of the pre-accession reform agenda of the 10 new member states (EU-10) that joined the European Union (EU) in 2004. ${ }^{1}$ In the early 1990s, subsidies were widespread in the EU-10 countries, with explicit subsidies representing on average 3 percent of GDP and implicit subsidies double this figure. The prospect of accession to the EU implied the need to comply with EU legislation and the system of European subsidies. As a result, the EU-10 countries had to modify, reduce drastically, and, in some cases, eliminate subsidies during the pre-accession period (1995-2004). Accordingly, they reduced spending on subsidies in their economic programs by an average of 50 percent.

During the pre-accession years, the key subsidy reforms took place in four areas: state aid to enterprises, as well as subsidies to agriculture, energy, and transport. Given their size and economic impact, the reforms of both aid to enterprises and subsidies to agriculture were of particular importance. Nevertheless, in all areas, the need to comply with EU regulations and directives guided the reform.

- $\quad$ Corporate subsidy reform was driven by the EU state aid regulation that required phasing out and eliminating any public support to inefficient companies.

- $\quad$ Agricultural subsidy reform was also triggered by the new EU Common Agricultural Policy (CAP). ${ }^{2}$ To prepare for EU membership, countries had to introduce CAP market organization and adapt their national mechanisms to the EU structural policy, including agro-statistical methodologies for data reporting.

- $\quad$ Reform in energy subsidies was motivated by the new EU directives for the liberalization of the gas and electricity markets. Consumer-oriented energy subsidies had to be transformed into producer-oriented and environmentally friendly subsidies.

- $\quad$ Similarly, EU directives on national road and railway transport contributed to the reform of transport subsidies. The strict requirements of the internal market regulation forced the new member states to guarantee equal access to all EU transport operators, forcing them to eliminate cross-subsidization between different transportation modes.

However, reform experiences varied widely across countries and types of subsidies. For example, the speed and sustainability of reform was different across countries (e.g., state aid reform in Cyrpus and Malta), resistance to reform was more prevalent in some sectors than in others (e.g., both Slovakia and Poland experienced internal opposition from farmers to agricultural subsidies' reform, while the reform of other subsidies proved easier), and even the outcome of reform varied both across countries and types of subsidies. Some of these

\footnotetext{
${ }^{1}$ The EU-10 countries are: Cyprus, the Czech Republic, Estonia, Hungary, Latvia, Lithuania, Malta, Poland, the Slovak Republic, and Slovenia. The EU-12 comprises the EU-10 countries, Bulgaria and Romania. The latter two joined the EU in 2007.

2 Typically, before accession to the EU, farmer support in the EU-10 countries was undertaken by state-owned enterprises through subsidy allocations, credit extensions, bank security, guarantees, etc.
} 
reforms are still taking place in a number of countries, often generating resistance and a fair amount of political debate. In some exceptional cases, countries have been able to obtain a temporary moratorium to build political support for reforms. ${ }^{3}$

This paper analyzes how key subsidy reforms were carried out in the EU-10 during 1995-2005 and draws lessons for successful reforms of government subsidies. ${ }^{4}$ It focuses on the four subsidy areas (state aid to enterprises, agriculture, energy, and transportation) and seeks to answer the following questions: (i) why did subsidy reform advance more for certain types of subsidies than others; (ii) why were some countries more successful in implementing and sustaining their subsidy reforms than others; and (iii) what lessons can be drawn from the experience for other countries undertaking subsidy reform?

The paper concludes that reforms depended largely on external and domestic factors. In particular, reform has been more successful in areas where external EU conditionality was firm, and such conditionality proved to be even more binding in countries where there was no domestic political consensus for reform. In contrast, when there was no external conditionality, domestic political factors played a major role in the reform process, and the presence of strong domestic opposition has often been a major impediment of the reform.

The rest of the paper is organized as follows: after providing a definition of subsidies, Section II describes briefly the process of subsidy reform in the EU-10; Section III develops a framework to explain the observed variation in the experiences of subsidy reform both across countries and types of subsidies; Sections IV to VII describe the reform process in each of the four sectors respectively and assess the sustainability of reform; and Section VIII draws policy lessons.

\section{OverView Of SubSidy Reform IN THE NEW MEMBER StATES}

\section{A. Concept and Definition}

For the purposes of this paper, a subsidy is defined as a government action that lowers the cost of production, raises the price received by producers, or lowers the price paid by consumers. ${ }^{5}$ This definition excludes direct transfers to households associated with the traditional policies of the welfare state (e.g., unemployment and pension benefits, subsidies for health and education services, etc.), which are typically classified separately in the EU

\footnotetext{
${ }^{3}$ Six out of the ten new member states negotiated and obtained transitional arrangements for state aid reform. All embraced the three-year transitory period before moving to the new CAP system. And few of them obtained concessions to fully apply the European Directives in the energy and transport sectors until 2008-09.

${ }^{4}$ Successful reform is defined as a reform that achieves the intended objective (e.g., reduction or elimination of the subsidy, change in the nature of subsidy, increase in prices to cost-recovery levels, higher transparency in the provision of subsidy, etc.).

${ }^{5}$ See Schwartz and Clements (1999) for a discussion on the definition, the measurement issues, and the economic effects of government subsidies. For a discussion on the economic determinants of government subsidies, see Clements, Rodriguez, and Schwartz (1998).
} 
budget classification system. ${ }^{6}$ Subsidies that are considered safety nets for poor people (e.g., food, housing, water, and sanitation subsidies) are also excluded. ${ }^{7}$ Instead, the focus is on price-distorting mechanisms such as those found in corporate, agricultural, energy, and transport subsidies.

Subsidy reform can be defined as a policy change in the nature and effects of the existing subsidies. ${ }^{8}$ Reform does not necessarily mean subsidy reduction; it can also imply a change in the nature of the intervention.

\section{B. From Transition to EU Accession}

\section{Subsidies were widely used in Central and Eastern European Countries (CEEC) prior to their transition to market economies. They were a key component of the centralized system of economic planning. Quantitative plans were used to set the "socially desirable" prices of goods and services. As a result, prices did not reflect the real cost of production of goods and services, leading many enterprises to experience either persistent losses or large profits, which were systematically corrected through budgetary subsidies or taxes.}

Subsidy reform in the CEECs started in early 1990s, during the transition to market economies. After the collapse of the Soviet Union, the CEECs started to reduce subsidies. Prices were allowed to reflect market-clearing levels in almost all manufacturing sectors, ${ }^{9}$ and almost all budgetary subsidies to enterprises in price-liberalized sectors were abolished. However, large-scale and rapid changes in the economic environment had an adverse impact on domestic enterprises in the coal, steel, energy, manufacturing, and agricultural sectors and forced governments to help these enterprises through different types of state aid.

\section{The commitment to subsidy reform was renewed in the mid-1990s with the Europe} Agreements. ${ }^{10}$ These agreements, whereby CEEC had to harmonize their legislation with EU rules, provided a new economic framework between the EU and each CEEC. Furthermore,

\footnotetext{
${ }^{6}$ The European System of Accounts (ECA 2000) classifies separately government subsidies and defines them as "current unrequited payments made by the general government to resident producers with the objective of influencing their levels of production, their prices or the remuneration of their factors of production.” Data on government subsidies in euros/local currency and as a percentage of GDP are collected by Eurostat, and updated quarterly in their AMECO database. By contrast, government transfers and subsidies are not differentiated in the Government Finance Statistics of the IMF, and therefore the latter does not report separate figures for both.

${ }^{7}$ For the concept and description of subsidies as social safety nets, see Alderman (2002).

${ }^{8}$ For a summary of best practices on price subsidy reform in developing countries, see Gupta and others (2000). For a discussion of compensatory measures for successful subsidy reform, see Pierce and von Finckestein (2000).

${ }^{9}$ Prices remained administered only in some sectors such as transport and housing.

${ }^{10}$ The Europe Agreements came into force at different points in time during the 1990s: Hungary and Poland (1994), Bulgaria, the Czech Republic, Romania, and the Slovak Republic (1995); Estonia, Latvia, and Lithuania (1998); and Slovenia (1999). Association Agreements were also in force with the two other new member states, Cyprus and Malta. The full text of the Europe Agreements with CEECs can be found on: http://www.europa.eu.int/comm/enlargement/pas/europe agr.htm.
} 
the criteria to join the EU set by the Copenhagen European Council in 1993-which included a well-functioning market economy, full price liberalization, and capacity to cope with competitive pressures and market forces within the EU-accelerated the pace of subsidy reform.

The EU accession negotiations (1998-2002) determined the reform conditions for each country. ${ }^{11}$ They focused on the terms under which the applicants had to adopt the acquis communautaire, ${ }^{12}$ and the possible granting of transitional arrangements. Applicant countries had to (i) comply with state aid regulation by eliminating or reducing substantially corporate subsidies; (ii) transform their agricultural subsidies to join the CAP; and (iii) reform their energy and transportation sectors to comply with the European Directives for gas, electricity, transport and renewable energies.

\section{Size and Composition of Subsidies}

Subsidies-to-GDP ratio was reduced by about 50 percent during the accession process. Subsidies in the EU-10 went down from 2.1 percent of GDP in 1995 to 1.2 percent of GDP in 2005 (see Table 1). Except in Estonia, where subsidies increased slightly, all countries have witnessed a decline in the subsidies-to-GDP ratio, with the strongest reductions taking place in Slovakia and Malta.

Table 1. Size of Subsidies (In percent of GDP)

\begin{tabular}{lrrrrrrr}
\hline & 1995 & 1998 & 2001 & 2002 & 2003 & 2004 & 2005 \\
\hline EU-15 & 1.6 & 1.4 & 1.3 & 1.3 & 1.2 & 1.2 & 1.1 \\
EU-10 & 2.1 & 1.6 & 1.4 & 1.3 & 1.4 & 1.4 & 1.2 \\
Czech Republic & 2.8 & 2.9 & 2.8 & 2.3 & 2.6 & 2.1 & 1.9 \\
Estonia & 0.7 & 1.0 & 1.0 & 0.9 & 0.9 & 1.5 & 1.0 \\
Cyprus & 1.5 & 1.0 & 1.4 & 1.1 & 1.2 & 1.1 & 0.7 \\
Latvia & 1.2 & 1.2 & 0.7 & 0.7 & 0.8 & 0.6 & 0.5 \\
Lithuania & 1.1 & 1.1 & 0.8 & 0.8 & 0.8 & 0.5 & 0.7 \\
Hungary & 2.1 & 1.6 & 1.7 & 1.8 & 1.5 & 1.6 & 1.6 \\
Malta & 3.3 & 2.2 & 1.6 & 2.2 & 2.2 & 2.0 & 2.1 \\
Poland & 0.8 & 0.6 & 0.4 & 0.4 & 0.3 & 0.3 & 0.3 \\
Slovenia & 2.4 & 1.9 & 1.5 & 1.3 & 1.7 & 1.6 & 1.6 \\
Slovakia & 4.7 & 2.9 & 2.1 & 1.5 & 1.7 & 2.2 & 1.3 \\
\hline
\end{tabular}

Source: European Commission, AMECO Database, 2006.

Eurostat defines subsidies as current unrequited payments made by the general government to resident producers with the objective of influencing the levels of production, thee prices or the remuneration of factors of production.

The composition of subsidy reduction varied considerably across countries and types of subsidy (Table 2). Corporate subsidies declined in most countries, while agricultural subsidies increased through the new CAP. Energy subsidies were cut in most countries, and

\footnotetext{
${ }^{11}$ Negotiations with Romania and Bulgaria were concluded later.

${ }^{12}$ It refers to the set of detailed laws and rules which form the basis of the EU Treaty.
} 
partially compensated for in some countries by new European resources for clean energies. Transport subsidies remained mostly unaltered at the national level due to incomplete railway reform, but reform took place at the urban level (bus and metro) and in freight transportation, to comply with the European legislation requiring free access to all operators and no cross subsidization.

\section{Table 2. Reductions in Subsidies by Type (In percent of GDP)}

\begin{tabular}{lcccc}
\hline \begin{tabular}{l} 
Subsidy reduction* \\
\multicolumn{1}{c}{ 2000-2005 }
\end{tabular} & State aid [a] & Agriculture [b] & Energy [d] & Transport [c] \\
\hline EU-15 & 0.0 & -0.1 & -0.3 & 0.0 \\
EU-12 & -0.2 & 0.3 & -1.2 & -0.1 \\
Czech Republic & -2.0 & -0.2 & -0.3 & 0.4 \\
Estonia & 0.3 & -0.1 & -1.1 & -0.5 \\
Cyprus & -0.6 & 0.0 & -0.2 & -0.2 \\
Latvia & -0.2 & 0.3 & 0.2 & -0.7 \\
Lithuania & 0.4 & 0.8 & -0.1 & -0.8 \\
Hungary & -0.1 & 0.2 & -2.3 & 0.5 \\
Malta & -0.2 & 0.3 & 0.1 & -0.3 \\
Poland & -0.6 & 0.3 & 0.2 & -0.3 \\
Slovenia & 0.1 & 0.2 & -0.8 & -0.6 \\
Slovakia & -0.1 & 0.2 & -0.8 & 1.1 \\
Bulgaria & -0.6 & 0.1 & -6.0 & 0.3 \\
Romania & -1.1 & -0.1 & -3.3 & 0.4 \\
\hline
\end{tabular}

Sources: European commission - DG COMP, State Aid Scoreboard, 2005 and DG Agriculture, AGRIS Database, 2006; World Bank ECA Infrastructure Database, 2005; International Energy Agency, 2006; and authors' estimations.

* Total subsidies in Table 1 are not equal to the sum of sectoral subsidies in Table 2 due to classification and source difference (b) State aid includes aid granted to specific sectors, excluding agricultural and railway subsidies, for horizontal objectives and for rescue and recovering of industries

(c) Agricultural subsidies include subsidies on agricultural products.

(d) Transport subsidies include subsidies to railway, road transportation, and maritime transportation.

(e) Energy subsidies include explicit and implicit subsidies in gas and electricity sectors.

\section{ANALYTICAL FRAMEWORK EXPLAINING DIFFERENCES IN SUBSIDY REFORM EXPERIENCES}

\section{A simple framework can be developed to explain variations of subsidy reform across} countries and types of subsidy. Subsidy reform in the context of EU enlargement and the "Europeanization" of the new member states can be conceived as a function of the interaction between external conditionality imposed by the EU and domestic political constraints. ${ }^{13}$ In a framework based on such a function, decisions would be driven by cost-benefit calculations of the reformist state faced with pressures from the EU (external conditionality) and domestic opposition (domestic political constraints).

\footnotetext{
${ }^{13}$ Europeanization is defined by Schimmelfennig and Sedelmeier (2005) as: "the process in which States adopt EU rules." See also March and Olsen (1989) for an interesting differentiation on the logics of rule adoption, based on consequences or on identification and appropriateness.
} 


\section{A. External Conditionality}

The degree of external conditionality explains mainly the differences in reform across types of subsidy. A high degree of external conditionality characterized all areas in which the EU exerted strong pressures on the new member states to comply in full with the acquis communautaire.$^{14,15}$ Where external EU conditionality was stronger, domestic constraints played a less important role and cross country variation of reform within each subsidy was lower (Figure 1).

Figure 1. External Conditionality and Variation of Reform Across Types of Subsidy Degree of External Conditionality

\begin{tabular}{l|l|l|l|} 
High & \multicolumn{2}{c}{ Low } \\
\hline Agriculture & State aid & Transport & Energy
\end{tabular}

- $\quad$ Agricultural subsidy reform faced the highest degree of external conditionality. This is because agricultural policy is profoundly embedded in EU treaties and is the first common policy transferred from the national to the Community level in the process of European integration. Countries had to reform their existing agricultural subsidies to comply with CAP. Conditionality was very strong: noncompliance meant non-accession while compliance allowed access to a larger pool of EU funds for agricultural policy reform.

- $\quad$ External conditionality was also very strong for state aid reform since it was viewed as a core component of the internal market. Commercial and competition policies are designed, monitored and enforced at the supranational (Community) level. Accordingly, the EU-10 had to reduce substantially and in most cases eliminate existing corporate subsidies that could affect free competition in the internal market.

- In contrast, the degree of external conditionality in energy and transport subsidy reforms was much lower. European Directives provided a framework for the development of national energy and transportation policies, but the core responsibility in these areas was not transferred to the Community level and compliance was not a pre-requisite for accession. ${ }^{16}$ As a result, the new member states were able to obtain transitory arrangements and often given additional years to implement the Directives.

\footnotetext{
${ }^{14}$ The acquis communautaire is set of detailed laws and rules which form the basis of the EU Treaty.

${ }^{15}$ Note that even before the EU actively promotes its rules in a certain area, nonmember states might engage in “anticipatory adaptation,” i.e., adopt EU rules in anticipation of the membership requirements (Haggard and others, 1993: 182).

${ }^{16}$ Only very recently, at the 2006 Spring European Council, member states started to take the first steps to build a common European energy policy. The report submitted by the Secretary General of the European Council to the Heads of Government and States dealt with flows, stocks, energy trade, and energy security for the whole
}

(continued...) 


\section{B. Domestic Constraints}

The degree of domestic constraints explains primarily the cross-country differences in reform within each type of subsidy. As external conditionality weakened, the role of domestic constraints in the reform process increased. Four types of constraint affected subsidy reform in the new member states:

(i) Unfavorable initial economic conditions. Low economic growth, high unemployment or inflation rate, as well as other unfavorable economic conditions made subsidy reform very difficult. For example, increasing tariffs to reduce the need for energy subsidies was very difficult when such increases generated affordability problems for poor households or created inflationary concerns.

(ii) Electoral constraints and power of domestic lobbies. A second factor that made subsidy reforms difficult was the relative political power of groups mostly affected by the reform (e.g., politically connected firms that would lose corporate subsidies or large farms that would stand to lose with the adoption of CAP—see Appendix II: Agricultural Subsidy Reform in Poland).

(iii) Fragmented decision-making process (decentralization). Fragmentation of decision making associated with incomplete decentralization created problems of coordination and authority, and thus complicated the reform process (e.g., local transportation authorities sometimes blocked the transposition of national laws based on European Directives).

(iv) Weak independent regulators. In countries where these regulators were relatively weak and could not manage to have price-setting power, subsidy reform was shallower than otherwise. For example, the reform of energy subsidies in Hungary was incomplete due to the weakness of the independent regulators.

\section{Subsidy Reform in the New Member States: Underlying Factors}

In most cases, the outcome of subsidy reform can be explained by the combination of external conditionality and domestic political constraints. Table 3 displays the different possible combinations of explanatory forces and the two clearest examples of subsidy reform within each category.

EU, in order to conform a comprehensive policy package that goes beyond the current EU Directives for gas and electricity, which merely focus on competition issues. 
Table 3. Key Cases of Subsidy Reform

\begin{tabular}{|c|c|c|}
\hline \multirow{2}{*}{$\begin{array}{l}\text { Domestic } \\
\text { Constraints }\end{array}$} & \multicolumn{2}{|c|}{ External Conditionality } \\
\hline & High & Low \\
\hline \multirow[t]{2}{*}{ High } & State aid reform in Cyprus & Energy subsidy reform in Hungary \\
\hline & State aid reform in Malta & $\begin{array}{c}\text { Transport subsidy reform in the Czech } \\
\text { Republic }\end{array}$ \\
\hline \multirow[t]{2}{*}{ Low } & Agricultural subsidy reform in Slovakia & Energy subsidy reform in Romania \\
\hline & Agricultural subsidy reform in Poland & Transport subsidy reform in Estonia \\
\hline
\end{tabular}

1/ See Appendix II for country experiences.

When both the degree of external conditionality and domestic political constraints were high, the reform was successful but countries often obtained transitory arrangements. For example, Malta and Cyprus were able to negotiate transitory arrangements in state aid reform because drastic state aid elimination in crucial economic sectors would have damaged their economies dramatically, and even have made EU accession undesirable.

When the degree of external conditionality was high but the strength of domestic constraints was low, the reform took place without transitory arrangements. For example, incomplete land reform and oligopolistic farming corporations in Slovakia and strong rural parties in Poland slowed down the modernization associated with the mandatory introduction of the CAP. However, these domestic constraints were not sufficiently strong to overcome the conditionality imposed by the EU and the external incentives (i.e., availability of large funds) associated with compliance. As a result, both countries were able to undertake a successful reform.

When the degree of external conditionality was low and the strength of domestic constraints was high, subsidy reform was limited and incomplete. Energy subsidy reform in Hungary and transport subsidy reform in the Czech Republic are the best examples. In both countries, the governments tried to comply with the minimum EU requirements in terms of market access to European companies, but political interference blocked the reforms: in Hungary, disputes between the government and the independent regulator slowed down the process, while in the Czech Republic, disputes among the government, the transport company, and the trade unions reduced the scope of reform.

Finally, when both the degree of external conditionality and the domestic constraints were weak, subsidy reform only occurred as a result of previous policy failure and strong domestic consensus and commitment. The cases of energy subsidy reform in Romania and transport subsidy reform in Estonia exemplify this. A cross-partisan consensus on the shape of the reform and the most adequate mechanism to protect the poor from tariff increases characterized energy subsidy reform in Romania. In Estonia, the decisive domestic push for privatization and market-oriented policies helped a long and gradual process of railway reform to succeed. 


\section{StATE Aid SUbSIDY REFORM}

\section{A. Situation Prior to Accession}

State aid granted annually in the EU-12 during 2000-02 was estimated at $€ 5.7$ billion or 1.4 percent of GDP (Table 4). ${ }^{17,18}$ The comparable figure for the EU-15 member states was $€ 34$ billion or 0.4 percent of EU-15 GDP. The four countries where the most state aid was awarded are: Poland (an annual average of $€ 2.4$ billion), the Czech Republic (an annual average of $€ 1.9$ billion), Romania (an annual average of $€ 0.91$ billion), and Hungary (an annual average of $€ 0.57$ billion). These countries accounted for 90 percent of total aid in the new member states. The highest levels in percent of GDP corresponded to Malta (3.9 percent), the Czech Republic (2.8 percent), and Cyprus (2.9 percent).

Table 4. State Aid in the New Member States, 2000-02

\begin{tabular}{lccccccc}
\hline & EU-15 & EU-12 & BG & RO & CZ & EE & CY \\
\hline State aid (in millions of euros) & 34,035 & 5,654 & 68 & 994 & 1,908 & 7 & 285 \\
State Aid (in percent of GDP) & 0.39 & 1.42 & 0.41 & 1.90 & 2.80 & 0.11 & 2.85 \\
Population (in millions) & 376.5 & 74.1 & 7.2 & 21.3 & 10.2 & 1.4 & 0.7 \\
$\begin{array}{l}\text { State aid per capita (in } \\
\text { thousands of euros) }\end{array}$ & 94 & 150 & 26 & 119 & 386 & 10 & 497 \\
\hline & & & & & & & \\
\hline State aid & 23 & LT & HU & MT & PL & SI & SK \\
State aid (in percent of GDP) & 0.26 & 0.24 & 1.04 & 3.86 & 1.29 & 0.69 & 0.51 \\
Population (in millions) & 2.3 & 3.4 & 10.1 & 0.4 & 38.2 & 2.0 & 5.4 \\
State Aid per capita & 21 & 22 & 114 & 601 & 127 & 100 & 51 \\
\hline
\end{tabular}

Source: European Commission, State Aid Scoreboard, 2004:17

\section{EU-12 used different instruments to finance state aid for manufacturing than the} EU-15. Several new member states tended to award aid through guarantees (41 percent) and tax exemptions (28 percent) rather than through grants (23 percent), which are more transparent and entail lower fiscal risks (Table 5).

\footnotetext{
17 The Berlin European Council in March 1999 agreement on the EU's budget for the period 2000-06 included $€ 22$ billion devoted to “pre-accession” assistance for infrastructure and institution-building (PHARE), environmental and transport infrastructure (ISPA), and rural development (SAPARD).

18 This section is based on the European Commission's State Aid Scoreboard (2004 and 2006). State aid figures provided in this section do not include agriculture, fisheries, and transport.
} 
Table 5. Instruments to Finance State Aid for Manufacturing and Services, 2000-02

\begin{tabular}{lcccccc}
\hline & Grants & $\begin{array}{c}\text { Tax } \\
\text { exemptions }\end{array}$ & $\begin{array}{c}\text { Equity } \\
\text { participations }\end{array}$ & $\begin{array}{c}\text { Soft } \\
\text { loans }\end{array}$ & $\begin{array}{c}\text { Tax } \\
\text { deferrals }\end{array}$ & Guarantees \\
\hline EU-15 & 58.6 & 24.0 & 5.6 & 6.0 & 2.6 & 3.2 \\
EU-12 & 22.4 & 28.5 & 3.1 & 2.9 & 1.9 & 41.1 \\
BG & 40.1 & 33.2 & 0.2 & 1.1 & 19.8 & 5.6 \\
RO & 21.2 & 27.4 & 1.1 & 0.3 & 44.1 & 5.9 \\
CZ & 11.7 & 3.4 & 5.6 & 1.3 & 0.4 & 77.7 \\
EE & 68.9 & 14.4 & 0.0 & 0.2 & 0.0 & 16.7 \\
CY & 17.9 & 80.9 & 0.0 & 0.0 & 0.0 & 1.2 \\
LV & 4.0 & 57.1 & 26.4 & 8.7 & 1.1 & 2.7 \\
LT & 41.1 & 15.6 & 9.6 & 5.2 & 0.7 & 27.8 \\
HU & 36.8 & 61.5 & 0.1 & 0.6 & 0.0 & 1.0 \\
MT & 19.1 & 36.6 & 0.0 & 33.4 & 1.4 & 9.6 \\
PL & 32.1 & 34.5 & 0.5 & 3.9 & 6.3 & 22.8 \\
SI & 46.4 & 33.2 & 10.8 & 5.8 & 0.0 & 3.7 \\
SK & 10.0 & 72.4 & 0.0 & 0.0 & 0.0 & 17.6 \\
\hline
\end{tabular}

Source: European Commission, State Aid Scoreboard, 2004: 25.

\section{B. The Process of Reform}

The enforcement of EU rules in the EU-12 triggered the reform of state aid. ${ }^{19}$ Before joining the EU, each country had to establish a state aid monitoring authority. This authority screened awards of state resources to determine whether they constituted state aid as defined under Article 87 of the EU treaty and whether they were compatible with the common market. Where state aid was identified incompatible with EU rules, countries had to adapt it, abolish it, or gradually phase it out. In addition, all accession treaties included a specific section to reduce or eliminate state aid.

State aid reform was fast and produced immediate results, both in terms of aid reduction and convergence

\section{towards EU-15 financing}

standards. In two years, the share of state aid in the EU-12 declined by 20 percent; the share of aid dedicated to horizontal objectives grew by 4 percentage points of total aid, with guarantees substituting for tax exemptions as the most preferred financing instrument (Table 6). The overall level of state aid at the end of the transitory period was targeted to drop from
Figure 2. State Aid Being Phased Out During Accession (in percent of GDP)

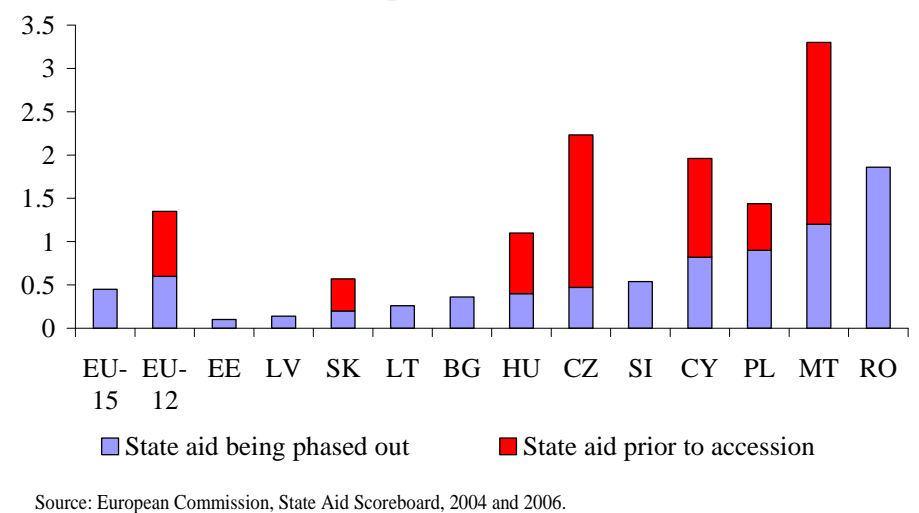

\footnotetext{
${ }^{19}$ See Appendix I for details on EU rules on state aid.
} 
1.42 to 0.67 percent of GDP for the 10 new member states (Figure 2). Most of this decline was concentrated in countries with the most difficult initial conditions, where the European Commission (EC) created joint supervisory teams with the local branches of government in charge of implementing the reform. At the end of the reform period, only Cyprus, Poland, and Malta were allowed to have state aid levels above the EU-15 average.

\section{Two types of aid proved particularly difficult to reform during the transition period.}

The first consisted of fiscal aid regimes incompatible with Article 87 of the EU treaty. This included tax breaks, tax holidays, and tax credits used to attract foreign investment to offshore arrangements. The second was aid used to bail out ailing industries, including enterprises that had tax arrears or difficulties in repaying loans.

Country-specific transitional arrangements were granted in most cases. This was done to avoid economically counterproductive reforms. Where fast and immediate reform was impossible, transitional arrangements were negotiated and granted. For example, because of the banking crisis, the Czech Republic was allowed to pay $€ 2.4$ billion in 2002 in the form of guarantees to restructure and subsequently privatize several banks. ${ }^{20}$ Six countries obtained gradual phasing-out conditions, and 278 cases were approved under the interim mechanism.

Table 6. The Effects of State Aid Reform

\begin{tabular}{|c|c|c|c|c|}
\hline State Aid (in percent of GDP) & \multicolumn{2}{|c|}{ EU-15 } & \multicolumn{2}{|c|}{ EU-12 } \\
\hline 2000-02 & \multicolumn{2}{|c|}{0.39} & \multicolumn{2}{|c|}{1.42} \\
\hline 2002-04 & \multicolumn{2}{|c|}{0.45} & \multicolumn{2}{|c|}{1.11} \\
\hline $\begin{array}{l}\text { State aid for horizontal objectives } \\
\text { (in percent of total aid) }\end{array}$ & \multicolumn{2}{|c|}{ EU-15 } & \multicolumn{2}{|c|}{ EU-12 } \\
\hline $2000-02$ & \multirow{2}{*}{\multicolumn{2}{|c|}{$\begin{array}{l}73 \\
68\end{array}$}} & \multirow{2}{*}{\multicolumn{2}{|c|}{$\begin{array}{l}21 \\
25\end{array}$}} \\
\hline 2002-04 & & & & \\
\hline Financing instruments & EU-15 & EU-15 & EU-12 & EU-12 \\
\hline (in percent of total aid) & 2000-02 & 2002-04 & $2000-02$ & 2002-04 \\
\hline Grants & 58.6 & 51.7 & 22.4 & 18.4 \\
\hline Tax exemptions & 24 & 31.6 & 28.5 & 37.5 \\
\hline Equity participations & 5.6 & 1 & 3.1 & 4.1 \\
\hline Soft loans & 6 & 5.3 & 2.9 & 2.4 \\
\hline Tax deferrals & 2.6 & 3.3 & 1.9 & 1.6 \\
\hline Guarantees & 3.2 & 7.1 & 41.1 & 35.9 \\
\hline
\end{tabular}

Source: European Commission, State Aid Scoreboard, 2004 and 2006.

\footnotetext{
${ }^{20}$ The outstanding amount of guarantees for bank restructuring amounts to $€ 6.5$ billion. Between 1994 and 1998, the Czech Republic faced a general banking crisis. The government adopted measures to facilitate the creation of a viable, privatized banking sector, and to restructure and privatize several banks. These measures included capital injections, transfers of assets, public guarantees, ring-fencing agreements, and litigation indemnities. The Czech authorities notified the EC of these cases under the interim mechanism procedure, and by the accession date, the EC declared 15 of these measures as "not applicable after accession;" the rest were allowed to remain under a progressive reduction scheme. As a result, the Czech Republic will reduce gradually state aid to the financial sector from 2.2 percent of GDP to 0.49 percent over a period of seven years.
} 


\section{The Sustainability of Reforms}

\section{State aid reform is likely to be sustainable for three reasons:}

- The inclusion of specific clauses in the new member states' accession treaties. These clauses require the convergence of state aid support and financing instruments to the EU-15 standards, whereby state aid should be either eliminated or redirected towards horizontal objectives. The latter may take time in many new member states, because it requires the development of new programs, and the previous agreement of European authorities.

- The focus on country-specific circumstances and the provision of transitional arrangements. This approach was especially important in small countries with a few sectors that were strongly affected by the reform (Cyprus and Malta), and in bigger countries with a single (though crucial sector) in crisis.

- The existence of national state aid control authorities. This is an unprecedented institutional novelty that was introduced during the accession years. The responsibility to monitor state aid was transferred from the national monitoring authorities to the EC, ${ }^{21}$ although national monitoring authorities continued to exist, and maintained some type of coordinating function in state aid matters and provided annual reports to the EC. ${ }^{22}$

\section{Agricultural Subsidy Reform}

\section{A. Situation Prior to Accession}

Most countries resumed support to agriculture in preparation to accession. In the early nineties, the liberalization of prices during the transition to a market economy resulted in drastic agriculture subsidy reductions in the region. In the Baltic countries, for example, the support of the agricultural sector even turned into a temporary taxation (EC, 1998). This downward trend was, however reversed in the early 2000s as EU accession approached and European funds started to arrive. Countries applied several intervention measures, ranging from cross-border measures and domestic floor prices to different types of payments, input subsidies, investment aid, and tax exemptions.

\footnotetext{
${ }^{21}$ Thereafter, new member states were required to inform the EC about any new aid measures. The EC would then decide whether or not to grant this aid.

${ }^{22}$ As the EC notes, "thanks to the considerable knowledge and national expertise acquired in state aid issues over the years through joint teams and prolonged discussions, these authorities are now able to advise national state aid grantors on community state aid rules, what facilitates the notification process, eases the compliance with the transitional arrangement and guarantees the stability of the reform” (EC, 2006a).
} 
Most of the increase in agricultural subsidies was channeled through the EU Special Accession Program for Agriculture and Rural Development (SAPARD) program. $^{23}$ This program shifted the composition of new agricultural subsidies towards rural development. SAPARD was designed to assist the new member states during their transitions to the CAP. The program included measures to enhance efficiency and competitiveness in farming and the food industry, and to create employment in rural areas. The initial program amounted to $€ 550$ million per year until 2006, and was targeted to improvements in rural

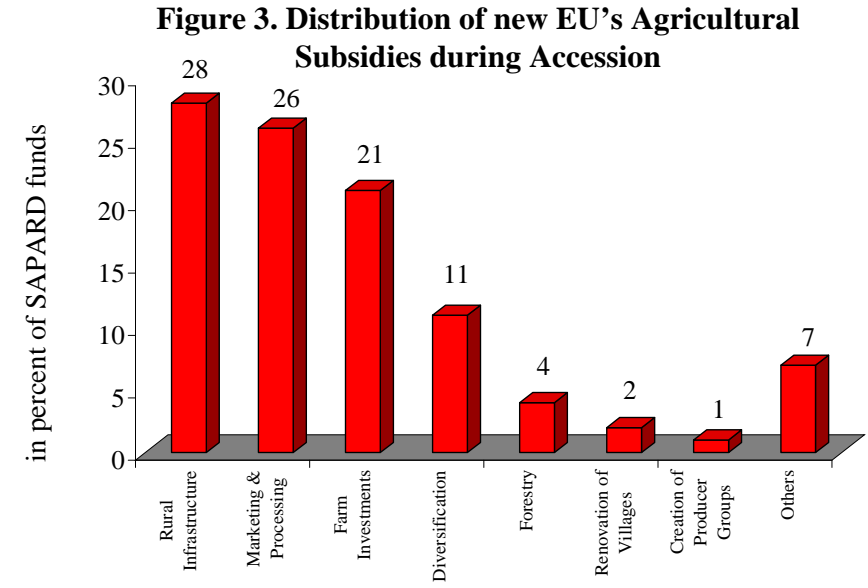

Source: European Commission, SAPARD, 2004. infrastructure, marketing and processing, and farm investments for modernization (Figure 3).

\section{B. The Process of Reform}

Agricultural subsidy reform was characterized by a gradual decoupling of subsidies from production and increased focus on rural development. Unlike for state aid, the new member states did not have to reduce their agricultural subsidies in order to join the EU. ${ }^{24}$ Instead, they had to phase in new programs gradually, which implied substitution of input and export subsidies with direct payment and rural development subsidies. Thus, agricultural subsidy reform was more a process of subsidy substitution than reduction. Accordingly, following the signature of accession treaties in 2003, agricultural subsidies in the new member states increased by an average of 0.16 percentage points of GDP (Table 7).

Eight member states implemented the Single Area Payment Scheme (SAPS). This scheme applies to the transitional period (2004-11) and consists of payments per eligible hectare of agricultural land up to a national ceiling set in the accession treaties. Farmers must meet certain standards of animal, plant, environment, and land quality to receive the payments. When farmers fail to meet these standards, direct payments are reduced or even eliminated. All new member states (except Malta and Slovenia) chose to apply the SAPS during transition.

Farmers also received direct payments during the first years of accession, although the magnitude of the payments was lower than in the EU-15. In particular, direct payments began to be gradually phased in, starting at 25 percent of the EU-15 level in 2004 and

\footnotetext{
23 The distribution of SAPARD funds, in millions of euros, was as follows: Bulgaria (53.1), the Czech Republic (22.4), Estonia (12.4), Hungary (38.7), Lithuania (30.3), Latvia (22.3), Poland (171.6), Romania (153.2), Slovenia (6.5), Slovakia (18.6), and Malta and Cyprus (20.1).

${ }^{24}$ See Appendix I for EU rules on agricultural subsidies.
} 
reaching 100 percent in 2013. New members were also given the possibility of topping up these payments with complementary national funds.

Table 7. Agricultural Subsidies in the New Member States (In percent of GDP)

\begin{tabular}{lrrrrrrrrr}
\hline & 1997 & 1999 & 2000 & 2002 & 2003 & 2005 & $1997-99$ & $2000-02$ & $2003-05$ \\
\hline EU-15 & 0.39 & 0.32 & 0.31 & 0.30 & 0.29 & 0.17 & -0.07 & -0.01 & -0.12 \\
EU-12 & 0.25 & 0.19 & 0.17 & 0.16 & 0.21 & 0.37 & -0.06 & -0.01 & 0.16 \\
Czech Rep. & 0.09 & 0.06 & 0.24 & 0.02 & 0.03 & 0.03 & -0.03 & -0.22 & 0.00 \\
Estonia & 0.27 & 0.29 & 0.26 & 0.20 & 0.21 & 0.21 & 0.02 & -0.06 & 0.00 \\
Latvia & 0.27 & 0.15 & 0.18 & 0.33 & 0.38 & 0.47 & -0.12 & 0.15 & 0.09 \\
Lithuania & 0.56 & 0.52 & 0.11 & 0.01 & 0.20 & 0.94 & -0.04 & -0.09 & 0.74 \\
Hungary & 0.36 & 0.19 & 0.16 & 0.26 & 0.27 & 0.44 & -0.17 & 0.10 & 0.17 \\
Malta & 0.10 & 0.06 & 0.01 & 0.04 & 0.22 & 0.27 & -0.04 & 0.04 & 0.05 \\
Poland & 0.13 & 0.04 & 0.04 & 0.06 & 0.06 & 0.38 & -0.09 & 0.03 & 0.32 \\
Slovenia & 0.21 & 0.17 & 0.14 & 0.19 & 0.26 & 0.33 & -0.04 & 0.05 & 0.07 \\
Slovakia & 0.19 & 0.15 & 0.15 & 0.14 & 0.18 & 0.40 & -0.04 & -0.01 & 0.22 \\
Bulgaria & 0.24 & 0.21 & 0.34 & 0.28 & 0.31 & 0.33 & -0.03 & -0.06 & 0.02 \\
Romania & 0.28 & 0.24 & 0.24 & 0.18 & 0.20 & 0.21 & -0.04 & -0.05 & 0.01 \\
\hline Source: Authors' calculation & based on Agriculture Database, Eurostat, 2006. & & & &
\end{tabular}

The process of reform was smooth in most countries in light of the close cooperation between local authorities and the $\mathrm{EC}$. Most countries identified specific units to manage the transition process in a joint effort with the EC. In some countries, the ministry of agriculture was directly responsible for this task, while in others with large funds, new agencies were created (e.g., the Polish Agency for the Reconstruction and Development of Agriculture).

The reform was more difficult in countries with dominant large-scale corporate farms that resulted from incomplete land reforms during the transition years. During the transition period, ex-communist countries returned expropriated land to the original owners. In some countries, such as Slovakia, Bulgaria, and Estonia, this restitution resulted in a dramatic increase in the power of large-scale farmers and a reduction in the presence of family farms. This happened because land ownership had been highly concentrated prior to communist collectivization, and the new legislation did not force the restituted owners to lease their land to small and medium farmers (Table 8). In such cases (e.g., Slovak Republic),

Table 8. Share of Different Farm Types in Total Agricultural Land (In percent)

\begin{tabular}{lcccc}
\hline & Family farms & Cooperatives & State enterprises & Private corporations \\
\hline Bulgaria & 38 & 42 & 6 & 14 \\
Czech Republic & 24 & 32 & 1 & 43 \\
Estonia & 39 & 12 & 25 & 24 \\
Hungary & 41 & 0 & 0 & 59 \\
Latvia & 95 & 0 & 1 & 4 \\
Lithuania & 50 & 10 & 20 & 20 \\
Poland & 84 & 2 & 6 & 8 \\
Romania & 67 & 12 & 21 & 0 \\
Slovakia & 12 & 47 & 3 & 27 \\
Slovenia & 96 & 0 & 4 & 0 \\
\hline
\end{tabular}

Source: Weingarten (2002: 11). Data is for year 2000. 
privatization during the transition did not imply an increase in competition and the large market power of the existing conglomerates gave them enormous political power to block reforms.

Agricultural subsidy reform also encountered difficulties in countries where farming structure was family-based and fragmented, and in cases where individual farmers had links with strong political parties. In Poland and Slovenia, where around 90 percent of farms were family based, agricultural-interest parties were very strong. In Slovenia, these parties opposed the SAPS mechanism and pushed for additional funds. In Poland, the rural parties took an even tougher stand and blocked the activity of the parliament, thus forcing the government to play harder in Brussels. In other cases, governments were able to insulate themselves from the agricultural interest groups and managed to adapt quickly to the new system. This typically occurred in countries (e.g., Lithuania) where rural parties where present at the regional level but had no strong partisan representation at the national level. Thus, the central government was able to negotiate EU accession without having to meet specific demands from farmers (Satuniene, 2003).

The reform had a very large positive impact on farmers' income in all countries. ${ }^{25}$ According to the EC (2006b, p. 106), "accession led to a dramatic increase of Figure 4. Agricultural Income in the Old and New average real agricultural incomes in EU-10, up in 2004-2005 by more than 70 percent as compared to the average between 1999 and 2003, while agricultural income in the EU-15 stagnated.” Farm incomes more than doubled in Estonia (+132 percent) and Latvia (+106 percent) and almost doubled in Poland (+95 percent) and Lithuania (+92 percent), pushing up the average for

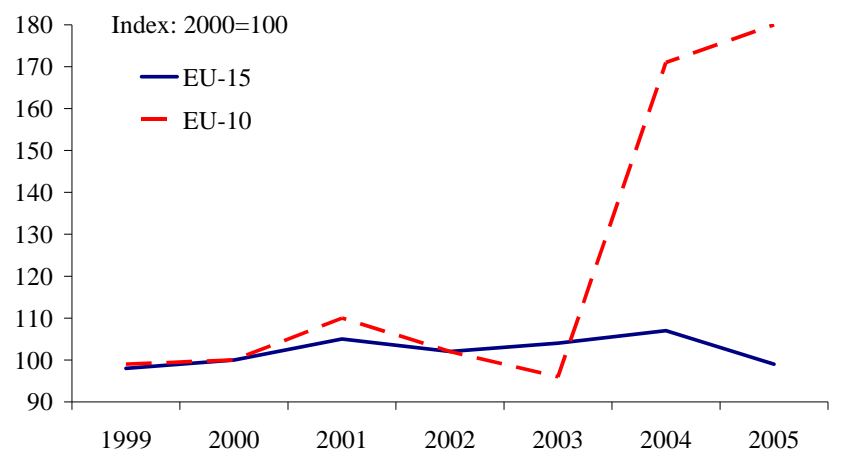
the whole region (Figure 4).

\section{The Sustainability of Reforms}

The short- and medium-term sustainability of agricultural subsidy reform is assured by the conditionality attached to the disbursement of CAP European funds. Direct subsidies associated with the SAPS are calculated according to production levels. Therefore, the greater the productivity, the larger is the subsidy that the new member states receive. This

\footnotetext{
${ }^{25}$ According to the OECD (2004 and 2005: 84) the estimated Producer's Support (PSE) increased in all new member states between 1995 and 2003 except in Poland. For example, the PSE increased in the Czech Republic from 11 percent to 29 percent of farmers' revenue; in Slovakia from 12 percent to 21 percent; in Hungary from 13 percent to 28 percent; in Slovenia from 37 percent to 42 percent; in Lithuania from 0 to 36 percent; in Latvia from 5 percent to 12 percent; and in Estonia from 0 to 19 percent. In contrast, the PSE went down in Poland from 16 percent to 8 percent of farmers' revenue.
} 
mechanism, together with the increasing trade between new and old member states, is creating market pressures for agricultural modernization and drastic restructuring of the food processing industries which will not be offset in the future.

The long-term sustainability of the whole CAP system of European agricultural funds is, in contrast, a more uncertain political issue. It will depend on future WTO negotiations and the internal EU discussion scheduled for 2009, prior to entering into the formal discussion of the next financial perspectives for the period 2014-2020.

\section{ENERGY SUBSIDY REFORM ${ }^{26}$}

\section{A. Situation Prior to Accession}

Governments in the EU, as in other countries, have historically manipulated energy prices through regulation, outright ownership, taxes, and direct or indirect support. Major policy objectives have typically included energy security, maintenance of certain levels of domestic energy production, and diversification of energy sources. Subsidies have also been used to provide access to energy to guarantee basic needs (such as heating, lighting, and cooking), to maintain employment or to develop certain regions.

Data show that energy subsidies systematically fell in most countries in the period prior to accession. ${ }^{27}$ In some countries, such as Hungary, Slovakia, Bulgaria, and Romania, the decline was beyond 60 percent. In Poland and Latvia, energy subsidies increased. ${ }^{28}$ Nevertheless, the overall picture is one of widespread subsidy reform that allowed the region to cut the size of energy subsidies in terms of GDP and approach the EU-15 average.

\footnotetext{
${ }^{26}$ Energy subsidies are typically defined as any government action that "lowers the cost of energy production, raises the price received by energy producers, or lowers the price paid by energy consumers" (IEA, 1999, p. 43). This broad definition includes both direct and indirect subsidies, explicit and implicit subsidies, and consumer and producer subsidies. Direct subsidies are transfers, grants, preferential loans, or insurance policies specifically targeted to certain consumers and/or producers to buy/sell energy. Indirect subsidies are regulatory mechanisms or systems of government management/ownership that affect the price at which broader groups exchange energy. Explicit subsidies are direct and publicly known transfers from the budget while implicit subsidies are not transparently recorded in the budget. Consumer subsidies lower the price of energy to households whereas producer subsidies increase the price of energy received by energy companies.

${ }^{27}$ Given the multiplicity of measures that governments have historically used to intervene in the energy sector, there are no standardized data available for energy subsidies. This implies that subsidies have to be calculated based on existing data on energy prices published for every country and type of energy source. Figures for explicit subsidies can be calculated using the price gap approach (comparing the actual end-use energy prices with reference prices, that is, those that would prevail in markets where there are no subsidies) (see IEA 1999, p. 71). Figures for implicit subsidies can be calculated by summing up the subsidy amount attributable to excessive system losses, that is, the sum of the amounts attributable to collection and pricing inefficiencies (see WB 2006, p. 40). Quarterly and annual data on prices and taxes for different energy sources are available from the International Energy Agency and from Eurostat.

${ }^{28}$ Both countries were granted a transitional arrangement to implement the provisions of the electricity market until 2008 and 2009, respectively.
} 
Cuts in implicit electricity subsidies were higher than those in gas subsidies. Some countries, such as the Czech Republic, Poland, and Lithuania, partially offset their cuts in electricity subsidies through increases in gas subsidies (Table 9).

It is, however, difficult to identify clear regional patterns of subsidy reduction despite the creation of different regional energy associations. Only Bulgaria and Romania, members of the South-East Europe Regional Energy Market launched by 10 countries in 2002, followed a similar path towards strong subsidy reduction. Smaller regional associations such as the Visegrad Energy Market (the Czech Republic, Poland and Slovakia) and the Common Baltic Electricity Market (Estonia, Latvia, and Lithuania) showed more heterogeneous behavior.

Table 9. Energy Subsidies in the New Member States, 2000-03

\begin{tabular}{lccc}
\hline Subsidy reduction (2000-03) & Electricity & Gas & Total \\
\hline EU-15 & -0.41 & 0.11 & -0.30 \\
EU-12 & -1.16 & -0.17 & -1.33 \\
Czech Republic & -0.44 & 0.17 & -0.27 \\
Estonia & -0.90 & -0.21 & -1.11 \\
Cyprus & -0.21 & 0.00 & -0.21 \\
Latvia & 0.12 & 0.11 & 0.23 \\
Lithuania & -0.13 & 0.03 & -0.10 \\
Hungary & -1.71 & -0.60 & -2.31 \\
Malta & 0.34 & -0.22 & 0.12 \\
Poland & -0.49 & 0.67 & 0.18 \\
Slovenia & -0.45 & -0.33 & -0.78 \\
Slovakia & -1.92 & -0.56 & -2.48 \\
Bulgaria & -5.65 & -0.36 & -6.01 \\
Romania & -2.47 & -0.80 & -3.27 \\
\hline
\end{tabular}

Source: World Bank ECA Infrastructure Database (2006).

\section{B. The Process of Reform}

Energy subsidy reform in the new member states was only compulsory in situations of illegal state aid support to energy producers. The EU legislation does not contain a specific regulation on energy subsidies, as it does for agricultural subsidy reform and state aid reform. ${ }^{29}$ The new member states were, therefore, not required to reform their energy subsidies, unless if the type of support they provided to energy producers was subject to state aid regulation. This meant that in those countries where an overall energy reform was decided, both consumer and producer subsidies were reformed. Otherwise, only producer subsidies that tried to sustain inefficient production disappeared under EU pressures, while various forms of consumer subsidies remained. In all cases, however, a major transition took place-mainly with EU co-financing (e.g., through tax relief and environmental funds) toward an increased use of subsidies aimed at promoting new technologies for energy

\footnotetext{
${ }^{29}$ See Appendix I for EU rules on energy subsidies.
} 
efficiency and the use of renewable energies (Table 10). ${ }^{30}$ Furthermore, all countries focused on the elimination of cross-subsidization of residential tariffs by industrial and commercial tariffs, though each country's experience was different.

Table 10. New Instruments for Promoting Renewable Energies in the New Member States

\begin{tabular}{cccccc}
\hline Feed-in Tariffs & $\begin{array}{c}\text { Quota } \\
\text { Obligations }\end{array}$ & Tenders & CO2 taxes & $\begin{array}{c}\text { Environmental } \\
\text { Funds }\end{array}$ & Tax Relief \\
\hline 7 COUNTRIES & 1 & 1 & 1 & 9 COUNTRIES & ALL \\
(all except BG, LT, & COUNTRY & COUNTRY & COUNTRY & (all except CY, & COUNTRIES \\
PL, SK, MT) & (PL) & (LT) & (SI) & MT, RO) & \\
\hline
\end{tabular}

Source: Reiche (2006:369).

Domestic political pressures were the primary driver of cross-country differences in both consumer and producer energy subsidy reform. For example, Slovakia implemented a range of thorough energy reforms over a short period of time with impressive results, while Hungary had to rely on a more gradual approach, due to the strong political influence that privatized generation and distribution companies still retained in Hungary. ${ }^{31}$

\section{Energy subsidy reform led to increases in energy tariffs, generating affordability problems and requiring social} intervention to offset the impact on the poorest households. ${ }^{32}$ With the increase in energy tariffs, energy spending as a share of household expenditure increased in all reforming countries during the accession period (Figure 5). Furthermore, according to World Bank ECA Household Surveys Archive (2005, p. 177), energy spending in the new member states was a larger share of household

Figure 5. The Impact of Subsidy Reform on Household Expenditures, 2000-03

\footnotetext{
${ }^{30}$ Funds for renewable energies typically complement external financial support received from international organizations. Grants are provided by the EU to local authorities, R\&D organizations, entrepreneurs, and individuals through the following programs: (i) Development Policy (ALTENER II, SYNERGY); (ii) Research and Development (JOULE/THERMIE, FP5); and (iii) Infrastructure (PHARE, ISPA, SAPARD, EIB/EBOIR). The United Nations provide loans to local authorities and enterprises through the Climate Protection Programmes (GEF, CIF) and the World Bank Infrastructure Support Facility.

${ }^{31}$ When price increases became necessary in 2000, the Hungarian government could not ignore the protests of these companies: it protected their margins by forcing the state-owned transmission company (which was also the single buyer in the wholesale market) to buy from privatized generation companies at a higher price and sell it to the distribution companies at a lower price.

32 According to the World Bank (2006, p. 52): "In the case of poor households, the increase in utility bills may force them to: (a) reduce their consumption to a level lower than desirable; (b) switch to unhealthy, dirtier or environmentally unsound choices; and (c) reduce consumption of other basic needs such as nutrition, clothes and healthcare."
} 
expenditures for poor households than for rich households. In Hungary, for example, energy spending represented 7.5 percent of total household expenditures for the poorest quintile of the population and only 4.5 percent for the richest quintile. Figures were similar in other reforming countries, such as the Slovak Republic (8 percent versus 6.5 percent), Bulgaria (11 percent versus 8.3 percent), and Romania (6.5 percent versus 5 percent).

Reformist countries used various instruments to ease the burden of tariff increases. Cross-subsidization from industrial to residential customers, toleration of nonpayment, and provision of targeted tariff discounts to the less privileged classes were commonly used methods for coping with affordability problems prior to accession. However, these instruments were against EU regulation, and thus not allowed during the accession process. Therefore, reformist countries used new alternative instruments, such as lifeline rates, burden limits, and earmarked cash transfers.

- $\quad$ Lifeline rates were used in Bulgaria, Hungary, and Romania. ${ }^{33}$ Romania introduced a system that gave the option to choose between a two-block system and the uniform pricing system. Instead, Hungary and Bulgaria put seasonal programs in place to assist vulnerable consumers during the heating season. ${ }^{34}$

- "Burden limit" approaches were adopted in the Slovak Republic and Latvia. ${ }^{35}$ In both countries, amounts above the specified percentage were paid by the government to the utility company. Such payments were limited to the notional amount of services to which the household was "entitled" (a pre-determined basic level of consumption).

- $\quad$ Earmarked cash transfers were adopted in Poland, Hungary, Latvia, Romania, and Bulgaria. ${ }^{36}$ These transfers were designed to cover a portion of the utility bills for families meeting a specified household income target and allowed for payment of utility bills only.

\section{The Sustainability of Reforms}

The sustainability of energy subsidy reform in the new member states will depend on the following related issues: (i) the privatization process during the transition period; (ii) the distribution of policy responsibilities between national and local authorities; and (iii) the consolidation of independent regulators.

(i) Subsidy reform prior to privatization is more likely to succeed. The region's experience in private participation in the power and gas sectors shows that privatization before adequate subsidy reform (i.e., ensuring payment discipline, introducing cost

\footnotetext{
${ }^{33}$ Lifeline rate means that the lowest block of consumption is charged at a rate substantially lower than the average tariff.

${ }^{34}$ See Appendix II.

${ }^{35}$ Under the "burden limit” approach, households are expected to pay a specified percentage of their household disposable income.

${ }^{36}$ Earmarked cash transfers consist of cash payments made to selected households.
} 
recovering tariffs, and credible regulatory arrangements) leads to serious problems for investors, who face uncertainty regarding the future of the sector. In addition, the experiences of the Czech Republic and Hungary confirm that privatization ahead of clear decisions on the desired structure for the sector makes it difficult to undertake and maintain desired structural and subsidy reforms later on. ${ }^{37}$ As a result, countries that privatized before reforming will find it harder to maintain energy subsidy reforms.

(ii) Decentralization with a clear distribution of responsibilities between different levels of government is also key to the sustainability of reforms. Municipalities that are heavily dependent on central government transfers due to low tax collection capacity (e.g., in Bulgaria and Hungary) have no incentives to introduce energy saving measures and higher tariffs. This is the case because the subsequent budgetary savings reduce the amount of the total transfers they receive from the central government instead of being redirected for other purposes. ${ }^{38}$ The experience shows also that financial problems emerged in several countries (e.g., in Latvia, Bulgaria, Romania, and Hungary), because of the ambiguous distribution of responsibilities between national and local authorities, which induced municipalities to set tariffs below cost.

(iii) Finally, the consolidation of independent regulators as strong institutions with price-setting authority is the most important challenge ahead for the sustainability of reform. The EU electricity and gas directives require the establishment of independent regulatory bodies outside the ministries responsible for the sector. All new member states created these independent regulators compliant with international standards (Table 11). ${ }^{39}$ In practice, however, many regulatory bodies are still subject to political interference. ${ }^{40} \mathrm{~A}$ special survey carried out by the EBRD in 2004 indicated that 50 percent of electricity regulators in the new member states were not allowed to serve out their full term. Line ministries responsible for infrastructure, industry, and energy sectors were reluctant to delegate responsibilities to the regulatory bodies, many of which actually continued to report to line ministries. In more than 30 percent of the cases, regulatory decisions were reversed by governments through decrees. In practice, prior government approval was needed in most countries for key tariff decisions, especially when these affected residential consumers (e.g., Hungary and the Czech Republic).

\footnotetext{
${ }^{37}$ See Krishnaswamy and Stuggins (2003).

${ }^{38}$ See Rezessy and others (2006).

${ }^{39}$ All regulators are separate from the supervisory ministry; most are given fixed-term tenures; many are financed from industry levies; and all adopted transparent procedures to review grievances caused by regulatory decisions.

${ }^{40}$ In some countries (e.g., the Czech Republic, Hungary, Lithuania, and Romania), the lack of delegating the full tariff-setting power to the independent regulators caused problems of underinvestment in energy security. In other countries (e.g., Bulgaria and Poland), some of the legal provisions approved to create these independent regulators are being circumvented.
} 
Table 11. Power Sector Regulatory Bodies in the New Member States

\begin{tabular}{cccccc}
\hline $\begin{array}{c}\text { Separate } \\
\text { Regulator }\end{array}$ & $\begin{array}{c}\text { Fixed-term } \\
\text { Appointment }\end{array}$ & $\begin{array}{c}\text { Industry } \\
\text { Funding }\end{array}$ & $\begin{array}{c}\text { Full tariff } \\
\text { power }\end{array}$ & $\begin{array}{c}\text { Transparency } \\
\text { procedures }\end{array}$ & $\begin{array}{c}\text { Redress and } \\
\text { grievance } \\
\text { procedures }\end{array}$ \\
\hline $\begin{array}{c}\text { ALL } \\
\text { COUNTRIES }\end{array}$ & $\begin{array}{c}\text { ALL } \\
\text { COUNTRIES } \\
\text { (except HU) }\end{array}$ & $\begin{array}{c}\text { COUNTRIES } \\
\text { (all except CZ, } \\
\text { EE, HU, SK) }\end{array}$ & $\begin{array}{c}\text { COUNTRIES } \\
\text { (all except CZ, } \\
\text { HU, LT, RO) }\end{array}$ & $\begin{array}{c}\text { ALL } \\
\text { COUNTRIES }\end{array}$ & $\begin{array}{c}\text { ALL } \\
\text { COUNTRIES }\end{array}$ \\
\hline
\end{tabular}

Source: World Bank (2006: 98).

\section{TRANSPORT SUBSIDY REFORM}

\section{A. Situation Prior to Accession}

Transport subsidies were significant and complex prior to accession. Their average size was 0.5 percent of GDP, with some countries like Latvia, Lithuania, and Slovenia showing figures close to 1 percent of GDP (Table 12). The system of subsidies was different for each type of transportation. Road and air transportation subsidies were typically explicit and given to semi-public companies. National railway subsidies consisted mainly of cross-financing mechanisms between passenger and freight transportation lines, within recently privatized companies. Finally, local transportation subsidies (bus, metro, and tramways) were a combination of direct aid to local transport providers and a system of controlled consumer prices.

Table 12. Transport Subsidies in the New Member States, 2000-05 1/ (In percent of GDP)

\begin{tabular}{lcccc}
\hline & 2000 & 2002 & 2005 & $2000-05$ \\
\hline EU-15 & 0.4 & 0.4 & 0.4 & 0.0 \\
EU-10 & 0.5 & 0.4 & 0.4 & -0.1 \\
Czech Republic & 0.5 & 0.8 & 0.9 & 0.4 \\
Estonia & 0.5 & 0.3 & 0.2 & -0.3 \\
Latvia & 0.8 & 0.4 & 0.1 & -0.7 \\
Lithuania & 0.9 & 0.2 & 0.1 & -0.8 \\
Hungary & 0.1 & 0.3 & 0.6 & 0.5 \\
Poland & 0.5 & 0.3 & 0.2 & -0.3 \\
Slovenia & 0.8 & 0.3 & 0.2 & -0.6 \\
Slovakia & 0.1 & 0.7 & 1.2 & 1.1 \\
Bulgaria & 0.1 & 0.4 & 0.4 & 0.3 \\
Romania & 0.3 & 0.5 & 0.7 & 0.4 \\
\hline
\end{tabular}

Source: World Bank Infrastructure Database (2006).

1/. Transport includes railway, road transportation, and maritime transportation. 


\section{B. The Process of Reform ${ }^{41}$}

\section{Although guided by the EU transport regulation, transport subsidy reform was mainly} driven by domestic policy decisions. ${ }^{42}$ The EU policy approach to transport is to intervene only when there are trans-border externalities or effects on the internal market, or to capitalize on possible economies of scale and policy spillovers. As a result, transport subsidy reform at the local level was not driven by EU accession, but by the financial difficulties inherited from the transition years.

The reform of transport subsidies did not change the level of subsidies during the accession period. Thus, between 2000 and 2005, transport subsidies declined only by 0.1 percentage points of GDP. Transport subsidy reduction was significant in the Baltic countries, Poland, and Slovenia (averaging a reduction of 0.6 percent of GDP over five years), while it increased in the Czech Republic, Slovakia, Hungary, Bulgaria, and Romania (by an average of 0.5 percent of GDP).

\section{The EU-10 countries received} European Funds through the ISPA program for funding transport reform required by the acquis. Since these funds were used mostly in co-financed projects with the member states, countries that received more ISPA funds (Figure 6) were also the ones that increased transport subsidies by a higher amount (the Czech Republic, Hungary, Bulgaria, and Romania). The only exception was Poland, the biggest recipient of ISPA funds, ${ }^{43}$ which reported an overall reduction in transport subsidies.

\section{Railway subsidy reform at the national level}

The adaptation to EU rules guided railway subsidy reform in the new member states. In an environment of stiff competition from road transport, railway companies in Eastern European countries faced a critical financial situation before EU accession that required decisive reforms. Although individual country circumstances varied widely, common solutions emerged as a result of the adaptation to EU legislation. This included splitting infrastructure from operations (passenger and freight transportation) to assure that

\footnotetext{
${ }^{41}$ This section will focus on the experience of railway subsidy reform and urban transport subsidy reform, because these are the two areas that concentrated the biggest amount of transport subsidies previous to EU accession and where most reforms took place.

42 See Appendix I for EU rules on transport subsidy.

43 ISPA provides financing to transport projects directly connected to the 10 pan-European corridors identified in these countries and to environmental projects to help countries apply directives that call for investment.
} 
infrastructure usage was priced efficiently, detaching functional lines from regional management lines, and establishing separate lines of business (including cost centers, subsidiaries within a holding company structure, or separately owned entities).

Railway subsidy reform resulted more in improved transparency rather than reduced subsidy. For example, in Poland, the government separated the operations that were subsidized for social reasons from the profit-making freight transportation. The need to renew infrastructure networks facilitated the new member states' cooperation with financial institutions such as the EBRD, the WB, and the USTDA (ECMT, 2001). This cooperation lowered the amount of subsidies needed to make the necessary investments.

A gradual approach was key to the success of railway subsidy reform, since a drastic process would have caused a popular reaction that could have blocked the reform.

Railway reform was generally part of an overall transport sector reform, which often implied, a reduction in the number of employees, partial privatization of state-owned companies, separation of business lines, implementation of open access to EU operators, investment in automatization, and improvement in administrative capacity. Drastic changes in these areas usually led to strikes and logistical problems that disrupted citizens’ lives.

\section{Domestic political consensus proved to be another key factor for successful railway} subsidy reform. For example, railway reform in the Czech Republic was temporarily blocked by lack of political consensus among the government, the opposition and the trade unions. In contrast, the full cross-partisan commitment of these groups in Romania was a crucial part of the success of the six-year three-stage reform (ECMT, 2005). ${ }^{44}$

\section{Urban transport subsidy reform at the local level}

Urban transport subsidy reform occurred in a context of financial difficulty and varied across countries. Urban transport suffered from a dramatic fall in demand (due to a fall in real wages and prices) and problems of technological backwardness on the supply side. In addition, a concurrent process of decentralization meant that local governments suddenly had large expenditure liabilities with ill-developed funding sources and mechanisms. As a result, urban subsidy reform varied widely among countries, cities, and utility types, depending on the initial conditions and the depth of the problems.

The reform process at the local level focused on reducing subsidies and increasing user fees. Transport subsidy reforms, at both national and local levels, sought to move service providers towards financial health, greater independence, and sustainability. However, there was a major difference across the two government levels. Subsidy reforms at the national level aimed at ending cross-subsidization through the separation of business lines and the transformation of cross-subsidies into direct transfers to operating units in loss. Subsidy reforms at local government levels aimed at achieving financial sustainability by introducing user fees (i.e., shifting the burden of financing subsidies from the government to consumers).

\footnotetext{
${ }^{44}$ The three stages of the reform are: (i) financial rehabilitation and end of cross-subsidization (1995-97);

(ii) institutional reform, separation of lines, and creation of a new Public Railway Authority (1998-2002); and

(iii) commercialization and privatization (1999-2003) (see Oliveschi, 2006).
} 
Raising user fees proved problematic in many countries where real cash incomes had collapsed, and, in some cases, the service levels had fallen and energy tariffs had been raised simultaneously. Groups enjoying special privileges (e.g., retirees in Riga-Latvia) were successful in organizing resistance in these countries, by using political pressure methods that became available with the transition to democracy. In most cases, consumers did not pay fares and service charges ${ }^{45}$ In contrast, rapid tariff increases did not create affordability problems and were not contested in countries where real wages and income per capita had increased considerably (e.g., Poland, the Czech Republic, and Slovenia). Accordingly the reform was faster in these countries. ${ }^{46}$

Tariff increases, democratic politics and subsidy reform at the local level also proved difficult to reconcile in countries where decentralization was not matched by sufficient transfer of resources. In the frontline reforming countries (e.g., Poland), local governments were given the jurisdiction over the provision of most local infrastructure and utility and transport services, but the scale and speed at which the ownership and responsibilities were transferred from the states to the cities were not matched by the scale of resource transfer or the increase in local resource mobilization. ${ }^{47}$ As a result, cities were faced with the contentious tasks of increasing user fees or cutting services-which was also undesirable since the new electoral democracy made local politicians dependent on voter's satisfactionand most cities failed to resolve this dilemma.

\section{The Sustainability of Reforms}

At the national level, transport subsidy reform in the new member states is likely to prevail in areas with full liberalization of services and the completion of the internal transportation market. This implies that the new member states will have to make sure that the legislation passed prior to accession, which allows any European transport company to provide services in their countries, is fully applied. It is only a question of time for this to actually happen. As trade between new and old member states increases and economic growth reaches these countries, major European companies' interest in operating in the new member states will increase. This will further increase the competition faced by national transport companies in all areas, and push further subsidy reform where it has not yet taken place.

\footnotetext{
${ }^{45}$ Anecdotal evidence from the medium-size Bulgarian cities, where service quality had dipped considerably, indicated that illegal travelers accounted for 50 percent of all travelers. In Riga, where fares increased but service remained the same, illegal traveler accounted for 17 percent for street and trolley buses, and 11 percent for metro lines.

${ }^{46}$ For example, both in Warsaw and Budapest, the cost recovery of public transport from fare revenues was quite low (20 percent in Budapest and 25 percent in Warsaw). Poland adopted a shock therapy approach to the changeover. In Warsaw, fare increases and other actions brought cost recovery in public transport services to about 70 percent, with some loss of service quality. In contrast, Hungary adopted a more gradual approach. In Budapest, which has a large-scale metro and suburban rail system, fares went up to cost recovery levels of 48 percent, and service quality was held by renewed subsidies.

47 "As regards city finance, turnover taxes on local enterprises were replaced by a combination of block grants from the central government and revenues to be generated from local taxes and user fees, with a gradual shift from the former towards the latter" (World Bank, 2002, p. 10).
} 
At the local level, further subsidy reform will be needed in the future. The gap between the collected fare revenue plus subsidies on the one hand, and operating costs on the other hand, persists in most cities. This is likely to require further painful interventions on both sides of the cost-revenue equation: overhaul of the fare/subsidy system, improved fare collection, and efficiency gains through internal changes and increased competition. The low scale of private participation in urban public transport and generally the near absence of competition in cities like Budapest, Prague, and Warsaw could also be a problem for their future performance.

If this funding gap persists over the medium term and results in a continued deterioration of urban public services, the private sector could fill the gap. This approach has been adopted by some by local authorities to circumvent the problems of public discontent associated with tariff increases and subsidy reform. For example, in Riga, the city administration started to issue permits to taxi-buses in large numbers without an explicit regulatory design. The evolution of these parallel private supply markets may provide service relief for some segments of the population, reduce the need for public capital investment, and demonstrate the case for greater cost-effectiveness in service provision, especially if based on competitive tendering and contract enforcement.

\section{Conclusions AND Policy Lessons}

The prospect of EU accession has been the main engine driving subsidy reform in the new member states. When external conditionality associated with EU accession was very strong, and the rules to follow were clear, reforms proved to be successful. External conditionality from international institutions (e.g., WB, IMF, and EBRD) also proved helpful to advance reform in cases where EU rules were not mandatory.

External conditionality explains differences in the outcome of subsidy reform across different types of subsidies. Evidence from the new member states shows a correlation between successful reform and strong external conditionality. Thus, reforms of state aid and agricultural subsidies have been more successful than reforms of energy and transport subsidies, because external conditionality was much stronger in the first two areas than in the second two. Before embarking in reforms that were always politically difficult, national authorities often used cost-benefit analyses based on three factors:

- $\quad$ Firmness of conditionality: the likelihood of strong subsidy reform increased if rules were set as unequivocal conditions for rewards.

- $\quad$ Size and speed of rewards: subsidy reform depended on the size and speed of rewards offered by the reform prospects. For example, compliance with state aid regulation pushed through strong subsidy reform because the reward (EU accession) was large and immediate.

- $\quad$ Credibility of conditionality: the likelihood of strong subsidy reform increased with the credibility of conditional threats. This depended on the relative capacity to impose sanctions (the more advanced the accession process, the more costly it was to stop it); the consistency with which the EU applied the rules (e.g., the politically motivated exclusion of the new member states from full CAP funding, decided in 2003, 
damaged EU's credibility among applicant countries); and the strength of monitoring mechanisms at the EU level.

Domestic factors explain the differences in the outcome of subsidy reform across countries. As external conditionality weakened, the role of domestic constraints in the reform process increased. The likelihood of strong subsidy reform increased when there was a strong domestic perception that existing subsidies where not working satisfactorily. The success of reform also depended on the initial economic conditions, the power of domestic lobbies, the decision-making process, and the strength of independent regulators.

Five broad lessons can be drawn from the subsidy reform experience of the new member states:

- $\quad$ First, fast reforms are possible only when there is an immediate and credible reward and a relatively favorable economic environment. For example, rapid tariff increases associated with subsidy reform were not socially contested since they took place in countries where real wages and income per capita had simultaneously increased. In contrast, gradual reform is preferable when the economic environment is unfavorable and/or subsidy reform is only one component of a more complex set of reforms in an entire sector (e.g., transport subsidies).

- $\quad$ Second, strong external conditionality and/or provision of incentives are necessary when there is no domestic political consensus for the reform. For example, agricultural reform in Slovakia and Poland took place despite domestic opposition, in light of the strength of the CAP. In contrast, the experiences of Hungary in energy subsidy reform and the Czech Republic in transport subsidy reform show that when reform remains incomplete when there is domestic opposition without strong external conditionality. Similarly, fragmentation of decision-making authority between levels of government (decentralization) or between the government and the regulator weakens the process of subsidy reform.

- $\quad$ Third, subsidy reform proves easier when it implies subsidy substitution and increased transparency, rather than subsidy reduction. The experience of railway reform (i.e., separation of business lines) shows that this type of reform can be as important as subsidy reduction. In this case, there were important gains from eliminating cross-subsidization and transforming the remaining subsidy into a simple public transfer. This reform did not initially imply reducing the size of subsidy and yet led to an increase in transparency.

- $\quad$ Fourth, subsidy reform that requires substantial expenditure cuts requires strong transitory arrangements. This is particularly important in small economies with many sectors at stake, or in large economies with a crucial sector in crisis. Crucial political consensus for subsidy reform is very hard to obtain without these temporary arrangements.

- $\quad$ Finally, subsidy reform, particularly of state aid to enterprises, should take place prior to privatization. This increases the chances of success because the private 
sector will behave according to well-defined market rules and incentives, rather than spend its energy on lobbying for the protection of the subsidies.

\section{Appendix I. Summaries of EU Rules}

\section{State aid}

The EU treaty regulates corporate subsidies. State aid regulation establishes that "a measure_-including subsidies_-constitutes state aid if it is granted by a member state or through state resources, affects prices and/or distorts or threatens to distort competition, favors certain undertakings or the production of certain goods, and/or affects trade between member states” (Art. 87, EU treaty).

The EU allows state aid for horizontal objectives as such aid targets market failures and is less distortive than sectoral aid. The four horizontal objectives under which the EU allows state aid are: measures for energy-saving, support to small and medium enterprises, research and development-employment aid, and regional development. In the years prior to accession, aid granted for horizontal objectives accounted for 22 percent of total aid compared to 73 percent in EU-15 (Table 13). Hence, over $3 / 4$ of state aid in the new member states was directed toward potentially more distortive sectoral aid (e.g., to rescue and restructure firms in difficulty).

\section{Agricultural subsidy}

The CAP sets the rules for agricultural subsidies in the EU. The first version of the CAP was adopted in 1962. It was built on guaranteed prices for farmers, export subsidies, and a high level of protection. The goals were to make Europe self-sufficient, modernize European agriculture, and guarantee a fair income to farmers. However, it led to overproduction, and reform started in 1984 with the milk quotas. In 1992, production subsidies were replaced by direct subsidies to farmers. In 2003, WTO negotiations and EU enlargement led to a third revision of the CAP, ${ }^{48}$ and the introduction of a new system of direct payments, known as the Single Area Payment Scheme (SAPS) ${ }^{49}$ under which aid would no longer be linked to production. After joining the EU, countries could also gain access to additional funds for income support for low-income farmers undergoing restructuring, to help meet EU standards, or for other specific support schemes. ${ }^{50}$

\footnotetext{
${ }^{48}$ Numerically, enlargement's impact on EU agriculture was dramatic. Four million farmers were added to the EU's existing 7 million and the arable land increased by 38 million hectares or 30 percent of total arable land, but added only 15 percent of production capacity (EC, 2006b).

${ }^{49}$ The main aim of the SAPS is to guarantee more stable incomes to farmers. Under the SPS, farmers can choose the crop they want to cultivate and adjust production to suit demand. To be eligible for the SAPS, a farmer would request payment entitlements, which would be calculated on the basis of historical payments received and the number of eligible hectares.

${ }^{50}$ Specific support schemes have been introduced or maintained for a variety of products (including rice, potatoes, milk, cotton, tobacco, and olive groves).
} 
Table 13. State Aid for Horizontal Objectives and Particular Sectors, 2000-02 1/

\begin{tabular}{lcc}
\hline & $\begin{array}{c}\text { EU-15 } \\
\text { (In percent) }\end{array}$ & $\begin{array}{c}\text { EU-12 } \\
\text { (In percent) }\end{array}$ \\
\hline Horizontal objectives (1) & $\mathbf{7 3}$ & $\mathbf{2 1}$ \\
R\&D & 15 & 2 \\
Environment & 16 & 2 \\
Small and Medium Enterprises (SME) & 15 & 2 \\
Employment aid & 4 & 5 \\
Regional aid & 24 & 10 \\
Sectoral aid (2) & $\mathbf{2 7}$ & $\mathbf{7 9}$ \\
Manufacturing & 3 & 26 \\
Of which: Shipbuilding & 1 & 2 \\
\multicolumn{1}{c}{ Steel } & 0 & 4 \\
Motor vehicles & 0 & 1 \\
Other non-manufacturing & 16 & 24 \\
Other (financial) services & 2 & 27 \\
\hline
\end{tabular}

Source: European Commission, State Aid Scoreboard, 2006, p. 13.

Note: All figures are expressed in euros at 2004 constant prices. (1) Aid for general regional development not elsewhere classified. (2) Aid for specific sectors awarded under measures for which there was no horizontal objective, as well as aid for rescue and restructuring.

1 . There is some cross country variation within this pattern. For example, in 2000-02, around 20 percent of state aid in Slovenia had employment objectives. Estonia and Slovenia directed around 15 percent of state aid to environment-against an average of about 2 percent in the new member states—and 15 percent of state aid to R\&D. Latvia favored the small and medium enterprises by granting them 32 percent of state aid against 3 percent in the rest of countries. Finally, Cyprus granted almost 10 percent for cultural purposes, theatre and film productions, and national broadcasting, well above any other candidate.

\section{Energy subsidy}

The declared objective of the EU's energy policy is "to ensure a supply of energy to all consumers at affordable prices while respecting the environment and promoting healthy competition on the European energy market" (EC, 2000). ${ }^{51}$

EU membership requires other policy changes. These changes consist of: (i) the progressive integration of the new member states into the EU internal energy market (lifting all trade restrictions); (ii) the possible co-funding of investment, including for energy efficiency and renewable projects by the EU structural regional funds; (iii) the enforcement of competition rules, including for mergers and acquisitions; and (iv) the direct EU monitoring of nuclear safety and planned decommissioning of least safe nuclear plants. Furthermore, EU membership requires the full and timely transposition of the gas, electricity

51 “Shaping a New Europe” COM(2000) 154 final. 
and renewable energies directives, especially in those aspects related with price transparency. ${ }^{52}$

\section{Transport subsidy}

The EU's earliest common policies covered the transport sector. Since the Treaty of Rome, EU transport policy has focused on removing obstacles at the borders of member states so as to facilitate the free movement of persons and goods. Two principles guided the EU transport policy: (i) any hauler established in a Member State may freely transport goods to any other member state; and (ii) any hauler must have equal access to transport infrastructure in any member state.

The EU has also established pricing policies for transport. This was done in 1995, through a Green Paper, ${ }^{53}$ which stated that the pricing system should be set to approach prices to costs and ensure equitable conditions for competition within and across modes on the internal transport market. The Green Paper required also a full internalization of transport costs, also that all consumers bear the full social costs of their use.

\section{Appendix II. Country Examples}

\section{State aid reform in Cyprus}

State aid reform in Cyprus is an example of fast subsidy reform motivated by strong external conditionality, and accompanied with transitional arrangements to deal with strong domestic contestation.

The reform of state aid in Cyprus took place in four years. Following the entry into force of the Public Aid Control Law (April 30, 2001), the Office of the Commissioner for Public Aid (headed by an independent official) was created to ensure the proper control for state aid reform. For this process to be successful, the reform had to focus on the two major schemes of state aid: the International Business Enterprises Act and the system of sectoral exemptions for import duties (88 percent of state aid was awarded under these schemes). The International Business Enterprises Act was a system of tax relief for international enterprises that allowed Cyprus to offer them a reduced corporate tax rate on benefits of 4.25 percent instead of the standard rate of 25 percent. Due to the size of the instrument and the likely impact on foreign direct investment, Cyprus negotiated a transitional arrangement for the first instrument until end of 2005. However, the pace of reform was fast: by end-2003, expenditure under this scheme had dropped to around $€ 68$ million from $€ 219$ million in

\footnotetext{
52 According to Council Directive 90/377/EEC of June 29, 1990: “Member states must ensure that gas and electricity undertakings communicate to the Statistical Office of the European Communities their prices, details of price systems in use and the breakdown of consumers (...) twice a year.” Thus, the Directives calls for improved transparency but does not cover energy price subsidies.

53 The Green Paper entitled, "Towards fair and efficient pricing in transport-policy options for internalizing the external costs of transport in the European Union" was approved on December 20, 1995.
} 
2002 due to the serious commitment of the Cyprus authorities, which introduced a new tax code that eliminated all incompatible fiscal aid with immediate effect and abolished the distinction between the onshore and offshore sector. As regards the sectoral exemptions for import duties, a transitional arrangement was also approved. Prior to accession, this system exempted most manufacturing enterprises from payment of import duties for certain raw materials, provided that these raw materials were used to manufacture final products. Although Cyprus had originally been required to immediately eliminate these measures on the date of accession, a transitory period of two years was granted to appease strong opposition from producers.

\section{State aid reform in Malta}

State aid reform in Malta is an example of gradual subsidy reform with transitional arrangements.

During the pre-accession period, Malta had the highest level of state aid as a percentage of GDP (3.86 percent on average), more than seven times the level of the EU-15, and almost three times that of EU-12. State aid consisted mainly of two aid schemes in the manufacturing (40 percent of total aid), and ship-building and ship-repair (50 percent of total aid) sectors. The Maltese government was aware that quick reform would have a very negative impact for economic performance and sought a more gradual reform process. Given the economic relevance of the sectors at stake (the manufacturing industry represented 18 percent of the Maltese net value added in 2004 and the ship-building and repair sector, 5 percent), Malta submitted to the EC three transitional requests for state aid. These requests were related to different BPA sub-schemes to support the SMEs, regional development, and the ship-building sector. After long negotiations, transitional arrangements until 2008 were conceded and included in the Accession treaty.

\section{Agricultural subsidy reform in Slovakia}

\section{Agricultural subsidy reform in Slovakia shows the importance of external conditionality for successful reform when domestic opposition is strong.}

During the nineties, market-oriented reforms in the Slovak Republic agricultural sector were incomplete. This was mainly due to the traditional approach to agriculture based on self sufficiency, balanced regional development, and income maintenance. Given the oligarchic structure of land ownership prior to communist collectivization, the process of land restitution of these properties was done without mandatory regulation for the use of this land and a framework to deal with the proliferation of medium-size competitive farms. In addition, land property rights were often not clearly defined, and remained unidentified as state land under the supervision of the State Land Fund which tended to lease it to large-scale farm corporations.

As a result, individual farm use in the Slovak Republic at the time of accession remained far behind other neighbors such as the Czech Republic, Romania, or Hungary. Only 12 percent of total land was in the hands of individual farmers. The rest was kept with large cooperatives or private corporations with twice the average size in the EU-12 and three 
times the average size in the EU-15. This situation reflected a policy bias in favor of the traditional socialist large firms. However, excessive size led to diminishing returns and inefficiencies: more than 50 percent of large corporate farms reported net losses between 1998 and 2003 and would have been unable to survive without state subsidies (Csaki and others, 2003).

These large inefficient farms resisted reform and exercised strong political power (derived from their control over 80 percent of the available land). In particular, they opposed any change in subsidies that would reduce their relative power or economic viability. As a result, the adaptation of the Slovak Republic to the market-oriented mechanisms in the CAP has been slower than in other countries. The same has occurred with the introduction of rural development subsidies, which have been often misused by large farmers.

\section{Agricultural subsidy reform in Poland}

Agricultural subsidy reform in Poland illustrates how reform can be imposed by strong external conditionality, and how strong domestic constraints can help improve the reward.

In December 2002, Poland agreed to the conditions of EU accession, including those that referred to a transitional approach to integrating new members into the CAP. Poland had initially objected to the proposal announced nine months earlier on two grounds: first, because it violated the principle that all member states in the EU have equal rights and privileges; and second, because given this unequal treatment, Poland did not want to open its borders to highly subsidized western products while simultaneously abandoning its domestic preferential credits and production subsidies. This heavily politicized dispute gave a large boost to the peasant and euroskeptic parties in the September 2002 elections, giving them 20 percent of the seats (Epsttein, 2005). Thus, they had the power to block any legislative activity in parliament and paralyze government activity. The associated pressures forced the government to negotiate hard with Brussels, even regarding Poland's future accession. The EU modified slightly the rules by which Poland would receive funds to transform it into the major future recipient under the new CAP. The expectation of large inflows of funds (around $€ 40$ billion between 2004 and 2006) reduced the power of the Polish threat of non-accession. As a result, European negotiators remained on their initial positions arguing that the agricultural chapter was nonnegotiable, even if that meant that Poland would not join the EU. This harsh exercise of EU conditionality forced agricultural subsidy reform in Poland.

\section{Energy subsidy reform in Romania}

The Romanian experience shows that in countries where both external conditionality and domestic constraints are weak, a consensus-based approach to energy reform is crucial for the successful introduction of a better targeted subsidy.

Within the framework of EU accession, and after the signature of the Athens memorandum in 2002 to join the South-East Europe Regional Energy Market (SEREM), the Government of Romania launched a Road Map for the Reform of the Energy Sector in July 2003. As a result, power prices increased, payment discipline improved, independent energy regulators were established, and the power and gas utilities 
were restructured. With the World Bank assistance, the government started to liberalize the price-setting mechanism on the basis of bilateral contracts. At the same time, it introduced a hybrid mechanism to mitigate the impact of price liberalization on the poor. According to this mechanism, customers could choose to pay a low marginal rate for the first consumption block and a higher marginal rate for additional consumption. Alternatively, they could choose optional tariffs based on constant marginal tariffs that fell somewhere between the two rates of the block tariff structure. Tariffs were set to make the block tariff attractive to basic consumers. The block tariff was not ideal from a pricing perspective, because the marginal tariff for the second consumption block was high relative to marginal cost and encouraged under consumption for one class of customers. However, it was a mechanism that targeted the poor more effectively during the reform process.

\section{Energy subsidy reform in Hungary}

The Hungarian experience shows that disputes between the central government and the regulator can slow down the process of subsidy reform in cases where external conditionality is weak and domestic constraints are strong.

As part of the process of creating an efficient competition-based domestic energy market, Hungary passed an Electric Power Act in 2001, and a new Gas Law in 2003. The gas sector was liberalized gradually, with an initial opening of the 25 percent of the gas market, and the creation of a new pricing mechanism set by an independent regulator, the Hungarian Energy Office (MEH). However, key pricing decisions for non-eligible consumers remained under government responsibility and despite the efforts made by the independent regulator to set prices that better reflect costs, the government insisted on keeping prices low for certain categories of consumers for social reasons. According to some analysts (Rezessy and others, 2006), this policy discouraged energy savings, distorted fuel choices and reduced energy security. Low prices discouraged investment in energy security by domestic energy firms such as MVM and the Hungarian Oil and Gas Company (MOL), because such a policy caused financial losses and rendered the economic viability of new investment uncertain. In the International Energy Agency's opinion, “the Hungarian government should have avoided possible conflicts of interest and given full responsibility to the $\mathrm{MEH}$, not only to calculate prices but also to set them” (IEA, 2003: 8).

\section{Transport subsidy reform in Estonia}

\section{The Estonian experience illustrates that reforming a complex industry requires a long- term process with supportive legislative, institutional, and management structures.}

The Estonian government restructured its railway (EVR) in a series of steps. In 1995, the government appointed a new senior management team, which divided EVR into separate business units for freight transport, passenger transport, infrastructure, and real state management. Under a new accounting system, public service contracts were dealt separately and cross-subsidization between different lines of business was reduced considerably. In 1997, most of EVR's loss-making (and still subsidized) lines and services were transferred to a new company, SWR, which was government-owned and responsible for most domestic passenger services. Meanwhile, EVR's freight operations became profitable, and cross- 
subsidization was eliminated. In 2000, the Estonian Privatization Agency announced the sale of 66 percent of the capital of EVR. This was the first vertically integrated transportation network to be privatized in Europe. Finally, in 2005, the government enacted new rules obligating the privatized company to open access to 100 percent of its freight infrastructure capacity in order to comply with EU requirements. The privatized company initially resisted this measure.

\section{Transport subsidy reform in the Czech Republic}

Disputes between the government, the public railway company (CD) and trade unions can slow down the process of subsidy reform in cases where external conditionality is low and domestic constraints are strong.

The Czech Republic's railway reform project was ready for approval early 2001. It consisted of separating the infrastructure and operations divisions to comply with the EU transport directives, and implementing a strategy to re-float the company and make it profitable. For many years, CD had kept itself afloat by using profits from rail freight to support its passenger operations. CD's freight operations produced a profit of 2.5 billion Koruna a year, but these results were overshadowed by an overall annual loss of 4 billion Koruna in the passenger services division. While all parties involved in the process of reforming CD agreed to transform it into a joint stock company initially owned entirely by the government, there was no consensus on the government's plan to write off CD's debts by selling shares of the operations to strategic partners, which would have immediately implied an end to cross-subsidization from operations to infrastructure. The final agreement came two years later when the government agreed to assume all the debts, with no additional partners, in order to give a fresh start to the new company. In addition, it appointed a board of directors (comprising a mix of management and trade union members) to supervise the management of the company. This slowed down the process of reform. While freight and operations were separated and given a fresh new financial start, the new company started its new era without specific plans to break up the freight and passenger divisions. In part because of the control that trade unions maintained over the new company, CD had to seek subsidies from the government in 2003 and 2004 to cover its loss- making local passenger services. In this context of low external conditionality and strong internal constraints, it is obvious that the end of cross-subsidization is likely to take longer than initially planned. 


\section{References}

Alderman, Harold, 2002, "Subsidies as a Social Safety Net: Effectiveness and Challenges," Social Protection Discussion Paper Series, 0224.

Checkel, Jeffrey T., 2001, “The Europeanization of Citizenship?” in Transforming Europe: Europeanization and Domestic Change, ed. by M. Green Cowles, J. Caporaso and T. Risse (Ithaca: Cornell University Press).

Clements, Benedict, Hugo Rodriguez, and Gerd Schwartz, 1998, "Economic Determinants of Government Subsidies,” IMF Working Paper 98/166 (Washington: International Monetary Fund).

Csaki, Csaba, Zvi Lerman, Antonio Nucifora, and Gejza Blaas, 2003, “The Agricultural Sector of Slovakia in the Eve of EU Accession,” Eurasian Geography and Economics, Vol. 44, pp. 305-20.

Dolowitz, David, and David Marsh, 2000, "Learning from Abroad: The Role of Policy Transfer in Contemporary Policy-Making,” Governance, Vol. 13, pp. 5-24.

Epstein, Rachel, 2005, "Diverging Effects of Social Learning and External Incentives in Polish Central Banking and Agriculture,” in The Europeanization of Central and Eastern Europe, ed. by F. Schimmelfennig and S. Ulrich S (Ithaca and London: Cornell University Press).

European Commission, 1998, “Agricultural Situation and prospects in the Central and Eastern European Countries,” Working Document (Brussels: DG AGRI).

, 2000, Shaping a New Europe (Brussels: Office of Publications of the European Communities-COM(2000)-154).

, 2004, State Aid Scoreboard-Autumn Update (Brussels: Office of Publications of the European Communities-COM(2004)-750).

, 2006a, State Aid Scoreboard-Spring Update (Brussels: Office of Publications of the European Communities-COM(2006)-130)

, 2006b, "Enlargement, Two Years After: An Economic Evaluation,” European Economy Occasional Papers, 24 (Brussels: Office of Publications of the European Communities).

European Conference of Ministers of Transport (ECMT), 2001, What Role for the Railways in Eastern Europe (Paris: OECD).

OECD). , 2005, Railway Reform and Charges for the Use of Infrastructure (Paris: 
International Energy Agency, 1999, World Energy Outlook-Looking at Energy Subsidies: Getting the Prices Right (Paris: IEA Publications Office).

, 2003, Energy Policies of IEA Countries-Hungary 2003 Review (Paris: IEA Publications Office).

Gupta, Sanjeev and others, 2000, Manual on Best Practices in Price Subsidy Reform (Washington: International Monetary Fund).

Haggard, Stephan, and others, 1993, "Integrating the Two Halves of Europe: Theories of Interests, Bargaining and Institutions," in After the Cold War: International Institutions and State Strategies in Europe, 1989-1991, ed. R. Keohane, J. Nye, and S. Hoffmann (Cambridge, MA: Harvard University Press).

Kennedy, David, 2005, “South-East Europe Regional Market: Challenge and Opportunities for Romania,” Energy Policy, Vol. 33, pp. 2202-215.

Krishnaswamy, Venkataraman, and Gary Stuggins, 2003, "Private Participation in the Power Sector in Europe and Central Asia: Lessons from the Last Decade,” World Bank Working Paper Series No. 8 (Washington: World Bank).

OECD, 2004, Agricultural Policies 2004-At a Glance. , 2005, Agricultural Policies in OECD Countries-Monitoring and Evaluation.

Olievschi, Vasile, 2006, "Learning from International Experience: Railway Reform in Romania.” Paper presented at the Dhaka World Bank Conference on Railway Reform, July.

Pearce, David, and Donata Finck von Finckestein, 2000, “Advancing Subsidy Reforms: Towards a Viable Policy Package,” CSERGE Working Paper GEC 2000-12.

Reiche, Danyel, 2006, "Renewable energies in the EU-Accession States,” Energy Policy, Vol. 34, pp. 365-75.

Rezessy, Silvia, and others, 2006, "Municipalities and Energy Efficiency in Countries in Transition. Review of Factors that Determine Municipal Involvement in the Markets for Energy Services and Energy Efficient Equipment, or How to Augment the Role of Municipalities as Market Players,” Energy Policy, Vol. 34, pp. 223-37.

Rose, Richard, 1991, “What is Lesson Drawing,” Journal of Public Policy, Vol. 11, pp. 3-30.

Šatūnienè, Živilè, 2003. "Political Economy of Lithuania's Membership in the Common Agricultural Policy (CAP),” mimeo.

Schwartz, Gerd, and Benedict Clements, 1999, “Government Subsidies,” Journal of Economic Surveys, Vol. 3, No. 2, pp. 119-30. 
Schimmelfennig, Frank, and Ulrich Sedelmeier (eds.), 2005, The Europeanization of Central and Eastern Europe (Ithaca and London: Cornell University Press).

Weingarten, Peter, 2002, “Transforming Agriculture in Central and Eastern Europe: Why Does it Take so Long?”, mimeo, presented at the Workshop on EU Structures organized by the Carl-Duisberg Society, Moldova, October 29-31.

World Bank, 2002, “Urban Transport in the Europe and Central Asia Region,” WIP Report, No 25188 ECA (Washington: World Bank, Infrastructure and Energy Services Department, Europe and Central Asia Region).

World Bank, 2005, Growth, Poverty and Inequality in Eastern Europe and the Former Soviet Union (Washington: World Bank).

, 2006, “Infrastructure in Europe and central Asia Regional Approaches to Sustainable Services”, mimeo (Washington: World Bank, Infrastructure and Energy Services Department, Europe and Central Asia Region). 